\title{
Temporal and spatial availability of cereal straw in Germany-Case study: Biomethane for the transport sector
}

\author{
André Brosowski ${ }^{1,2^{*}} \mathbb{D}$, Ralf Bill ${ }^{3}$ and Daniela Thrän ${ }^{1,2,4}$
}

\begin{abstract}
Background: By 2030, the German transport sector needs to achieve additional greenhouse gas savings of 67 million tonnes $\mathrm{CO}_{2}$-eq. and further progress requires swiftly implementable solutions. The fermentation of cereal straw is a promising option. Returning the digestate to the farmland can close agricultural cycles while simultaneously producing biomethane. The world's first large-scale, mono-digestion plant for straw is operational since 2014. The temporal and spatial biomass availability is a key issue when replicating this concept. No detailed calculations on this subject are available, and the strategic relevance of biomethane from straw in the transport sector cannot be sufficiently evaluated.

Methods: To assess the balance of straw supply and use, a total of 30 data sets are combined, taking into account the cultivation of the five most important cereal types and the straw required for ten animal species, two special crops and 12 industrial uses. The data are managed at district level and presented for the years 2010 to 2018. In combination with high-resolution geodata, the results are linked to actual arable fields, and the availability of straw throughout the country is evaluated using a GIS.
\end{abstract}

Results: During the analysis period and based on the assumption that in case of fermentation up to $70 \%$ of the straw can be utilised, the mobilisable technical biomass potential for future biomethane production is between 13.9$21.5 \mathrm{Tg} \mathrm{fm} \mathrm{a}{ }^{-1}$. The annual potential fluctuates considerably due to weather anomalies. The all-time maximum in 2014 and the minimum for the last 26 years in 2018 are separated by just 4 years and a difference of $7.6 \mathrm{Tg} \mathrm{fm}$. However, large parts of the potential are concentrated only in a few regions and biomethane from straw could provide 57-145 PJ of a low-emission fuel, saving 3-12 $\mathrm{Tg} \mathrm{CO}_{2}$-eq. in case of full exploitation.

Conclusion: Despite the strong fluctuations and high uncertainties, the potential is sufficient to supply numerous plants and to produce relevant quantities of biomethane even in weak years. To unlock the potential, the outcomes should be evaluated and discussed further with stakeholders in the identified priority regions.

Keywords: Biomass potential assessment, Biofuels, Bioeconomy, Substitution, GIS analysis

*Correspondence: andre.brosowski@dbfz.de

1 Deutsches Biomasseforschungszentrum Gemeinnützige $\mathrm{GmbH}$, Torgauer Str. 116, 04347 Leipzig, Germany

Full list of author information is available at the end of the article

\section{Background}

On 12 December 2019, the European Commission announced that Europe is to become the first climateneutral continent by 2050 [1]. Since 1990, the international base year, greenhouse gas (GHG) emissions in Germany have been reduced by $30.8 \%$ (as of 2018 ) [2, 3]. However, this level must be at least $55 \%$ by 2030 . While original author(s) and the source, provide a link to the Creative Commons licence, and indicate if changes were made. The images or other third party material in this article are included in the article's Creative Commons licence, unless indicated otherwise in a credit line to the material. If material is not included in the article's Creative Commons licence and your intended use is not permitted by statutory regulation or exceeds the permitted use, you will need to obtain permission directly from the copyright holder. To view a copy of this licence, visit http://creativecommons.org/licenses/by/4.0/. The Creative Commons Public Domain Dedication waiver (http://creativeco mmons.org/publicdomain/zero/1.0/) applies to the data made available in this article, unless otherwise stated in a credit line to the data. 
some significant reductions have been achieved in the source groups of households, commerce/trade/the service sector, industry and energy management, the current energy-related emissions in the transport sector are at the same level as in 1990 [2]. The German Climate Protection Act [4], which was introduced on 17 December 2019, thus calls for a GHG reduction of at least $67 \mathrm{Tg}$ $\mathrm{CO}_{2}$-eq. in this sector [5]. The National Platform on the Future of Mobility [6], a steering group convened by the Federal Ministry of Transport and Digital Infrastructure, is currently discussing three fields with regard to technology: electromobility, hydrogen/fuel cells and alternative fuels for internal combustion engines. The latter include e-fuels and biomass-based fuels, which are capable of reducing GHG emissions even in the existing fleet by 2030. Beyond 2030, there is particularly great potential for use in areas which are difficult to electrify, such as maritime shipping and heavy goods vehicle (HGV) traffic [6]. When it comes to the use of biomass in the transport sector, biomethane, among other things, is proving a promising option for replacing fossil fuels and for significantly reducing GHGs [7-9]. In that context, however, the use of energy crops is viewed critically [6], as so far it is not possible to manage sustainability requirements sufficiently [10]. The latest European and German strategy papers (e.g. the EU Renewable Energy Directive [11], the National Climate Action Plan [3] or the National Bioeconomy Strategy [12]) thus focus clearly on biogenic byproducts, residues and wastes.

The difference that can be made in the transport sector depends, inter alia, on the raw materials which are available and how they are specifically used. In mid-2019, Brosowski et al. [13] established a cross-sectoral monitoring system for 77 biogenic by-products, residues and wastes in Germany. This instrument can be employed at national level to assess the balance of raw material supply and use and contextualise the findings. If, for example, all the mobilisable technical biomass potential were used in the transport sector in the form of biomethane, large quantities of fossil fuels could be replaced for individual modes of transport-from the point of view of resources, at least [14]. These include, for example, passenger cars, HGVs or vessels previously powered with gasoline, diesel or heavy oil. Independently of the numerous techno-economic challenges for the use of biomethane (e.g. infrastructure, distribution, engine technology, methane slip, costs, etc. [15-17]), the paper explores the question of which limitations arise from the temporal and spatial biomass availability. The focus was put on cereal straw. Based on residue monitoring, this biomass is considered as the most important biogenic resources that are yet to be mobilised for the future production of biomethane [13]. So far, however, the monitoring system has only published findings for the reference year 2015, and only on national level. However, the annual production of cereal straw is linked to cereal production, and the agricultural production system is subject to temporal and spatial fluctuations. Figure 1 shows how cereal production, acreage and yield have developed over time since 1961. The illustration covers five cereal types-wheat, barley, rye, oats and triticale-which account for around $91 \%$ of all cereals (including maize) cultivated in Germany [18].

From 1961 to 2018, a reduction in acreage $(-11 \%)$ was offset by a significant increase in yield $(+149 \%)$. During that period, the production volume more than doubled (+123\%). In the last 20 years, however, considerable annual fluctuations in production of several million

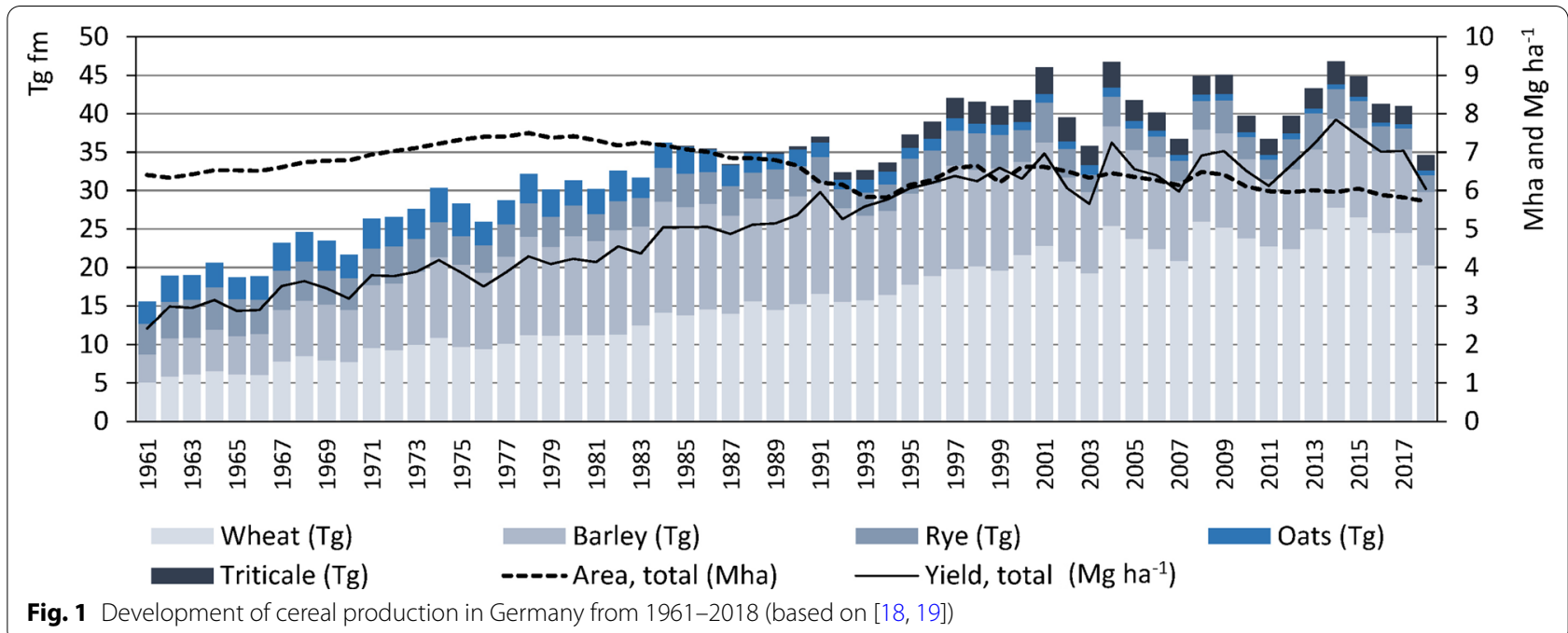


tonnes can be seen. The biggest slumps since 1961 took place in 2002 and 2018. Compared to previous years, the amount harvested dropped by around seven million tonnes. At the same time, these weak years are followed by very strong years. The highest level, almost 11 million tonnes, was in 2004. The second highest, at more than eight million tonnes, was four years later in 2008. These fluctuations are caused, among other things, by weather anomalies. The extremely weak years saw very high rainfall in 2002 [20] followed by a drought with the hottest summer since weather records began in 2003 [21], drought in the spring of 2007 [22], low levels of rain and late frosts in the spring, then heavy rain during the harvest season in 2011 [23], and the second hottest summer with numerous extreme regional values in 2018 [24, 25].

To date, there has not been any sufficient description of how the dynamic interplay of time and space might affect the future use of cereal straw. As a result, the associated risks, especially in connection with its existing use, cannot be adequately assessed. The aim of this article is thus to add a temporal dimension to the monitoring system established by Brosowski et al. [13] and at the same time depict the supply and use of resources with high spatial quality. The subject of how to assess the biomass potential of straw is controversial. Examining multiple studies (e.g. Weiser et al. [26], Scarlat et al. [27], Lindner et al. [28]), it can be seen that the calculation of theoretical potential is methodologically consistent. Cereal production figures are multiplied by grain-straw ratios from the literature. There are differences, among other things, in the number of cereal species considered, the times studied or the source data. The methodological differences are significant, however, when it comes to calculating the technical potential of straw. Key questions in this context include: how much is it technically feasible to harvest? Does straw required for bedding count as a restriction on the amount that can be used [26] or does it count as material use [13]? What is the amount required to maintain the humus content? The latter question in particular polarises the discussion about the future increased industrial use of cereal straw. Weiser et al. [26], for example, assume that industrial use requires straw to be removed, causing a loss. This argument treats various possible uses in material flow management (e.g. incineration, ethanol production, fermentation, etc.) as equal. However, the fermentation of cereal straw offers interesting opportunities for reproducing humus and improving the nutrient balance by returning digestate to the farmland, while simultaneously producing biomethane as an energy source [29-31].

In relation to the debate about the technical biomass potential of straw, this means that with this type of use, significantly higher amounts of straw would be available than indicated by Weiser et al. [26]. This article takes up the idea of this type of use and quantifies the role that biomethane produced from straw could potentially play in the transport sector. As well as the high relevance of this raw material and the intense pressure to take action in the transport sector, this focus is also based on the fact that the world's first large-scale industrial TRL-9 plant with straw mono-digestion is already being operated successfully in Germany [32]. This offers the opportunity to multiply an already proven plant concept and provide a short-term contribution to reduce GHG emissions in the transport sector.

\section{Methodology}

Against this background, the methodological approach addresses two key aspects. Firstly, the residue monitoring calculation method developed by Brosowski et al. [13] is consistently transferred from national to regional level and analysed for the years 2010 to 2018 . Secondly, the processing of the temporal and spatial data is tested based exclusively on the example of the production of biomethane, including digestate return. Chapter 2.1 describes the steps required to prepare the data. Chapter 2.2 explains how the data generated were analysed with the help of a Geo-Information System (GIS) [33] to identify particularly relevant regions for the future mobilisation of raw materials, using the European NUTS system to describe the territorial levels [34].

\section{Calculation and contextualisation of cereal straw potentials}

Consistently transferring the calculation methodology from the present national level (NUTS-0) to Germany's current 401 districts (NUTS-3) [35] requires extensive data preparation. Table 1 summarises the 30 sets of source data used and their availability. The "National Monitoring" column refers to the national calculation methodology developed by Brosowski et al. in 2019 [13] and the "Regional Monitoring" and "Data Set" columns describe the data sets used for consistent calculation at regional level. The table also shows the spatial and temporal qualities of the data sets and their unit of measurement. The respective sources are summarised beneath the overview. At this level of detail, a distinction between conventional and organic farming is not yet possible. However, at least in the statistical databases the respective shares are indirectly included as the sum of both systems. 
Table 1 Overview of the data used to calculate the regional supply and use of cereal straw in Germany

\begin{tabular}{|c|c|c|c|c|c|c|c|c|c|c|c|c|c|c|}
\hline \# & $\begin{array}{c}\text { National } \\
\text { monitoring }\end{array}$ & $\begin{array}{l}\text { Regional } \\
\text { monitoring }\end{array}$ & Dataset & $\begin{array}{c}\text { Available } \\
\text { spatial } \\
\text { level }\end{array}$ & Unit & ํํำ & $\overline{\overline{\bar{N}}}$ & สิ & $\stackrel{m}{\bar{N}}$ & है & $\stackrel{n}{\bar{N}}$ & อั & 록 & $\stackrel{\text { ก }}{\overline{3}}$ \\
\hline 1 & Cereal & Yield & \multirow{3}{*}{$\begin{array}{l}\text { Wheat, rye, barley, } \\
\text { triticale, oats }\end{array}$} & \multirow{2}{*}{ NUTS-3 } & $\mathrm{dt} \mathrm{fm} / \mathrm{ha}$ & $\checkmark$ & $\checkmark$ & $\checkmark$ & $\checkmark$ & $\checkmark$ & $\checkmark$ & $\checkmark$ & $\checkmark$ & $\checkmark$ \\
\hline 2 & production & Acreage & & & ha & $\checkmark$ & \multicolumn{5}{|c|}{ LI } & $\checkmark$ & \multicolumn{2}{|c|}{ LI } \\
\hline 3 & \multicolumn{2}{|c|}{ Grain-straw ratio } & & NUTS-0 & 1: & $\checkmark$ & $\checkmark$ & $\checkmark$ & $\checkmark$ & $\checkmark$ & $\checkmark$ & $\checkmark$ & $\checkmark$ & $\checkmark$ \\
\hline \multicolumn{4}{|c|}{ Theoretical biomass potential } & NUTS-3 & $\mathrm{tfm}$ & $\checkmark$ & $(\checkmark)$ & $(\checkmark)$ & $(\checkmark)$ & $(\checkmark)$ & $(\checkmark)$ & $(\checkmark)$ & $(\checkmark)$ & $(\checkmark)$ \\
\hline 4 & \multicolumn{2}{|c|}{ Collection ratio } & \multirow{2}{*}{$\begin{array}{l}\text { Wheat, rye, barley, } \\
\text { triticale, oats }\end{array}$} & \multirow{2}{*}{ NUTS-0 } & $\%$ & $\checkmark$ & $\checkmark$ & $\checkmark$ & $\checkmark$ & $\checkmark$ & $\checkmark$ & $\checkmark$ & $\checkmark$ & $\checkmark$ \\
\hline 5 & Humus balance & Recovery for bio-CH4 & & & $\%$ & $\checkmark$ & $\checkmark$ & $\checkmark$ & $\checkmark$ & $\checkmark$ & $\checkmark$ & $\checkmark$ & $\checkmark$ & $\checkmark$ \\
\hline \multicolumn{4}{|c|}{ Technical biomass potential } & NUTS-3 & $\mathbf{t f m}$ & $\checkmark$ & $(\checkmark)$ & $(\checkmark)$ & $(\checkmark)$ & $(\checkmark)$ & $(\checkmark)$ & $(\checkmark)$ & $(\checkmark)$ & $(\sqrt{ })$ \\
\hline 6 & \multirow{15}{*}{ Animal bedding } & \multirow{10}{*}{ Livestock } & Dairy cows & \multirow{4}{*}{ NUTS-3 } & \multirow{10}{*}{ Heads } & $\checkmark$ & $\checkmark$ & $\checkmark$ & $\checkmark$ & $\checkmark$ & $\checkmark$ & $\checkmark$ & $\checkmark$ & $\checkmark$ \\
\hline 7 & & & Other Cattle & & & $\checkmark$ & $\checkmark$ & $\checkmark$ & $\checkmark$ & $\checkmark$ & $\checkmark$ & $\checkmark$ & $\checkmark$ & $\checkmark$ \\
\hline 8 & & & Pigs & & & $\checkmark$ & & & LI & & & $\checkmark$ & $\mathrm{I}$ & J \\
\hline 9 & & & Sheep & & & & & & $L 1$ & & & & & \\
\hline 10 & & & Chicken & \multirow{10}{*}{ NUTS-1 } & & & & & & & & & & \\
\hline 11 & & & Geese & & & & & & & & & & & \\
\hline 12 & & & Ducks & & & $\checkmark$ & $\mathrm{L}$ & I & $\checkmark$ & L & I & $\checkmark$ & $\mathrm{L}$ & I \\
\hline 13 & & & Turkeys & & & & & & & & & & & \\
\hline 14 & & & Goats & & & & & & & & & & & \\
\hline 15 & & & Horses & & & & base & $\mathrm{d}$ on 2 & 015 & & $\checkmark$ & base & $\mathrm{d}$ on 2 & 2015 \\
\hline 16 & & \multirow{4}{*}{ Type of husbandry } & Cattle & & & & \multirow{4}{*}{\multicolumn{8}{|c|}{ based on 2010}} \\
\hline 17 & & & Pigs & & Animal & $\checkmark$ & & & & & & & & \\
\hline 18 & & & Sheep & & places & & & & & & & & & \\
\hline 19 & & & Chicken & & & & & & & & & & & \\
\hline 20 & & Bedding requirem. & All types of animals & NUTS-0 & $\mathrm{tfm}$ & $\checkmark$ & $\checkmark$ & $\checkmark$ & $\checkmark$ & $\checkmark$ & $\checkmark$ & $\checkmark$ & $\checkmark$ & $\checkmark$ \\
\hline 21 & Not considered & Fodder & Horses & NUTS-0 & $\mathrm{tfm}$ & $\checkmark$ & $\checkmark$ & $\checkmark$ & $\checkmark$ & $\checkmark$ & $\checkmark$ & $\checkmark$ & $\checkmark$ & $\checkmark$ \\
\hline 22 & \multirow{5}{*}{\multicolumn{2}{|c|}{ Special crops }} & Strawberries (open field) & \multirow{2}{*}{ NUTS-1 } & \multirow{2}{*}{ ha } & $\checkmark$ & $\checkmark$ & $\checkmark$ & $\checkmark$ & $\checkmark$ & $\checkmark$ & $\checkmark$ & $\checkmark$ & $\checkmark$ \\
\hline 23 & & & Strawberries (under foil) & & & $\checkmark$ & $\checkmark$ & $\checkmark$ & $\checkmark$ & $\checkmark$ & $\checkmark$ & $\checkmark$ & $\sqrt{\checkmark}$ & $\checkmark$ \\
\hline 24 & & & Demand for strawberries & & $\mathrm{t} / \mathrm{ha}$ & $\checkmark$ & $\checkmark$ & $\checkmark$ & $\checkmark$ & $\checkmark$ & $\checkmark$ & $\checkmark$ & 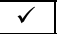 & $\checkmark$ \\
\hline 25 & & & White mushrooms & NUTS-0 & ha & & I & $\checkmark$ & $\checkmark$ & $\checkmark$ & $\checkmark$ & $\checkmark$ & $\checkmark$ & $\checkmark$ \\
\hline 26 & & & Demand for mushrooms & & $\mathrm{t} / \mathrm{ha}$ & $\checkmark$ & $\checkmark$ & $\checkmark$ & $\checkmark$ & $\checkmark$ & $\checkmark$ & $\checkmark$ & $\checkmark$ & $\checkmark$ \\
\hline 27 & \multirow{4}{*}{\multicolumn{2}{|c|}{ Industrial use }} & Packaging & \multirow{4}{*}{$\begin{array}{c}\text { Site } \\
\text { specific }\end{array}$} & $\mathrm{t} \mathrm{fm}$ & $\checkmark$ & $\checkmark$ & $\checkmark$ & $\checkmark$ & $\checkmark$ & $\checkmark$ & $\checkmark$ & $\checkmark$ & $\checkmark$ \\
\hline 28 & & & Combustion & & $\mathrm{t} \mathrm{fm}$ & $\checkmark$ & $\checkmark$ & $\checkmark$ & $\checkmark$ & $\checkmark$ & $\checkmark$ & $\checkmark$ & $\checkmark$ & $\checkmark$ \\
\hline 29 & & & Biomethane production & & $\mathrm{t} \mathrm{fm}$ & $\checkmark$ & $\checkmark$ & $\checkmark$ & $\checkmark$ & $\checkmark$ & $\checkmark$ & $\checkmark$ & $\checkmark$ & $\checkmark$ \\
\hline 30 & & & Ethanol production & & $\mathrm{t} \mathrm{fm}$ & $\checkmark$ & $\checkmark$ & $\checkmark$ & $\checkmark$ & $\checkmark$ & $\checkmark$ & $\checkmark$ & $\checkmark$ & $\checkmark$ \\
\hline & technical bioma & potential & & NUTS-3 & $\mathrm{tfm}$ & $(\checkmark)$ & $(\checkmark)$ & $(\checkmark)$ & $(\checkmark)$ & $(\checkmark)$ & $(\checkmark)$ & $(\checkmark)$ & $(\checkmark)$ & $(\checkmark)$ \\
\hline
\end{tabular}

LI: linear interpolation, : data set available, (): data set contains interpolations. Sources: \#1: [36]; \#2: [37]; \#3: [38]; \#4-5: calculated based on Table 2; \#6-7: [39]; \#8-9: [40]; \#9-14: [41]; \#15: [41, 42]; \#16-19: [43]; \#20: [38]; \#21: [44]; \#22: [45]; \#23: [46]; \#24: [47]; \#25: [48]; \#26: [49]; \#27: [50]; \#28: [51]; \#29: [52]; \#30: [53]

Altogether, the availability of the data that is required is very heterogeneous, and four different approaches are taken to data preparation:

- Direct data transfer: the data can be taken directly from the statistics with the required spatial and temporal qualities (NUTS-3 and annual).

- Interpolation of missing years: due to the structure used to collect the statistical data, only certain years are available. Here, missing years were linearly interpolated based on the available data points.

- Spatial data weighting: data are available for certain years, but not at NUTS-3 level. Here, the finding in question was weighted and transferred from the available level to the corresponding NUTS-3 level.

- Generation of new data: as yet unavailable data sets on current industrial use were collected by gathering primary data.
There are tonnages for cereal production at national level in Germany, but none at NUTS-3 level. To calculate the required data, the yields of the five available cereals (\#1) were thus multiplied by the acreage (\#2). However, the acreage is not available for every year, but only for the years 2010 and 2016. The missing years were linearly interpolated based on these two data points. In combination with the grain-straw ratio (\#3, Table 2), it was possible to fully calculate the theoretical cereal straw potential at NUTS-3 level. The amount which can be used to produce biomethane was based on the findings gathered by Reinhold [31] and the results of the Germany-wide very first field trials by Knebl et al. [29]. The results show that returning the digestate to the farmland can have positive effects on the humus and nutrient balance. Hence, a large quantity of the straw remains in the agricultural cycle, which is not possible with other industrial uses than fermentation. The technically feasible recovery of straw by combine harvesters is only carried out up to a certain stubble 
Table 2 Basic data on calculation of total straw recovery (based on [38, 54-56])

\begin{tabular}{|c|c|c|c|c|c|c|c|c|}
\hline \multirow[t]{2}{*}{ Data set } & \multirow{2}{*}{$\begin{array}{l}\text { Grain-straw } \\
\text { ratio } \\
\text { 1: }\end{array}$} & \multirow{2}{*}{$\begin{array}{l}\text { Stubble height } \\
\mathrm{m}\end{array}$} & \multirow{2}{*}{$\begin{array}{l}\text { Growth height } \\
\mathrm{m}\end{array}$} & \multirow{2}{*}{$\begin{array}{l}\text { Feasible } \\
\text { collection ratio } \\
\%\end{array}$} & \multirow{2}{*}{$\begin{array}{l}\text { Recovery for } \\
\text { biomethane production } \\
\%\end{array}$} & \multicolumn{3}{|c|}{ Total recovery } \\
\hline & & & & & & $\%$ & Average & \\
\hline Wheat & 0.8 & 0.10 & $0.50-1.50$ & $80-93$ & 80 & $64-74$ & 69 & 71 \\
\hline Rye & 0.9 & & $1.50-2.00$ & $93-95$ & & $74-76$ & 75 & \\
\hline Barley & 0.7 & & $0.70-1.20$ & $86-92$ & & $69-74$ & 72 & \\
\hline Triticale & 0.9 & & $0.50-1.25$ & 80-92 & & $64-74$ & 69 & \\
\hline Oats & 1.1 & & $0.60-1.50$ & $83-93$ & & $66-74$ & 70 & \\
\hline
\end{tabular}

height. To stop the mower from being clogged, the minimum height is $10 \mathrm{~cm}$ [54]. Along with the growth heights of the cereal types shown in Table 2, this results in a technically feasible collection rate $(\# 4)$ of between 80 and $95 \%$. If an assumed $80 \%$ of this is made available for biomethane production, the average removal rate is around $70 \%$ in all (\#5). This means that $30 \%$ of the straw remains untouched on the field and after fermentation of the removed quantities, the digestate is returned to the farmland. This type of application is associated with numerous open questions which are further elaborated in the discussion (Chapter 4). However, this assumption enables the estimation of a technical potential for further temporal and spatial analyses and to evaluate the strategic significance of straw-based biomethane in the transport sector.

Some of the technical potential of straw is already being used for various purposes. The regional calculation over time takes into account (a) bedding for ten animal species, (b) feed requirements for horses, (c) requirements for special crops and (d) requirements for industrial use.

(a) Bedding Calculating the amount of straw used for bedding requires data on the animal population, husbandry and animal-specific bedding requirements. The stock of dairy cows (\#6) and other cattle (\#7) can be taken directly from the official statistics with the required quality. Data on pigs (\#8) and sheep (\#9) are available at NUTS-3 level, but only for 2010 and 2016. Data for poultry (\#9-13) and goats (\#14) are also available for 2013, but in total only at NUTS-1 level. Missing years were linearly interpolated. The database on horses (\#15) is particularly incomplete. Official statistics only record numbers in agricultural farms [57]. The number of commercial or recreational horses is not included and is only recorded by the federal states' livestock disease funding associations. For data protection reasons, these data are not publicly available. Taking the reference year 2015, Uhl [42] published a telephone comparison survey at NUTS-1 level. The number of horses reported was almost twice that in the statistics. Uhl [42] points out that not all horses are registered with the disease funding associations and that the actual number could be significantly higher. For this reason, only the figures provided by Uhl [42] are taken, as a consistent database for all the years under consideration. The animal population was then linked to the type of husbandry (\#16-19) and the animal-specific bedding quantities (\#20). Data on husbandry are only available to the public for the year 2010 and for NUTS-1 level. Time series interpolation is not possible. Literature-based, animal-specific bedding quantities are also constant and only available at NUTS-0 level. On this basis, no different requirements for organic husbandry can be considered so far. The calculation of the bedding quantities follows the methodology proposed by Weiser et al. [26] and can be summed up in the following formula. The calculation values are found in Annex A.

$$
S i=\sum(A n-(A n \times G p \times G d)) \times H s m \times B a
$$

$\mathrm{S}_{i}$ : straw used as bedding $\left(\mathrm{Tg} \mathrm{fm} \mathrm{a} \mathrm{a}^{-1}\right) ; \mathrm{A}_{n}$ : number of animals; $\mathrm{G}_{p}$ : share of grazing (\%); $\mathrm{G}_{d}$ : duration of grazing period per year (\%); $\mathrm{H}_{s m}$ : share of animals in strawbased housing systems (\%); $\mathrm{B}_{a}$ : Bedding requirements $\left(\mathrm{Mg} \mathrm{a}^{-1}\right)$ for every livestock subcategory.

As the numbers of poultry, goats and horses are only available at NUTS-1 level, the data were then weighted spatially. First, the resulting bedding quantities were calculated at NUTS-1 level. Relating this to the technical potential of straw at NUTS-1 level comes up with a percentage for the animal-specific bedding quantities. This weighting was then transferred to each NUTS-3 region. Taking one example, this means that in a NUTS-1 region with ten NUTS-3 units, there is a technical straw potential of $1000 \mathrm{Mg} \mathrm{fm}$, and $250 \mathrm{Mg} \mathrm{fm}$ was calculated as the bedding requirement, producing a weighting percentage of $25 \%$. That value was then multiplied by the individual technical potential in each of the ten NUTS-3 units.

b) Horse feed requirements In addition to bedding, straw can also be used as a food supplement or for 
chewing to prevent boredom. Depending on the breed, an average feed requirement (\#21) of $0.42 \mathrm{Mg} \mathrm{fm}$ per animal and year is indicated in the literature [44]. That value was applied to the animal numbers in question (\#15) and weighted regionally as described.

c) Special crops The cultivation of strawberries and mushrooms also requires straw. Growing data on strawberries (\#22-23) are available annually at NUTS-1 level, while those on mushrooms (\#25) are only at NUTS-0 level and only from 2012. The two missing years were linearly interpolated. Requirements were calculated in combination with literature-based straw requirements (\#24, \#26) [47, 49], weighted and applied to NUTS-3 level.

d) Industrial use As yet, there are no public data sets on this type of straw use. Therefore, primary data were collected for the four fields of packaging (\#27), incineration (\#28), fermentation (\#29) and ethanol production (\#30). A review of various sources (see Table 1) was used to determine the exact plant locations, straw requirements and start of production.

The overall outcome of the data processing was that the technical potential used for all 401 NUTS-3 units and for the years 2010 to 2018 was consistently compiled and calculated. The difference between the technical potential and the utilisation is known as the mobilisable potential [13]: the proportion which could be used for the future production of biomethane. The basic data in Table 3 were used to further contextualise the mobilisable potential.

On this basis, the substitution potential for fossil fuels and the associated GHG reduction potential were estimated for the selected transport modes passenger cars, heavy goods transport and maritime shipping. This leads primarily to an initial indicative statement and not to a detailed life cycle assessment (LCA). For this reason, general bandwidths were used for the calculations in order to cover the numerous uncertainties as best as possible. In addition to the basic data on biomethane production (e.g. methane yield), an overall efficiency between 70 and $85 \%$ was assumed according to Scholwin et al. [15]. This bandwidth includes, for example, transport losses in biomass supply, methane losses and the energy requirements of biogas purification, grid feed-in, gas distribution, etc., in a very general manner. In this way, other forms of supply such as compressed (CNG) or liquefied (LNG) biomethane are also covered. A bandwidth was also assumed with regard to the GHG mitigation potential. The extensive, straw-specific calculations conducted by Majer et al. [62] and the estimates of Scholwin et al. [15] result in a range between 60 and $85 \%$. On this basis, the numerous influencing parameters caused by transport, conversion and distribution were also covered from a very general perspective. The contextualisation is based on the idea of replicating the concept of the world's first successfully operated, large-scale industrial TRL-9 plant for straw mono-digestion. The annual straw requirement is about 40,000 Mg.

\section{Hotspot assessment}

When the use of raw materials within a NUTS-3 region grows higher than the supply of raw materials, the additional demand must be balanced out by other regions. Weiser et al. [26] describe all regions with a deficit as

Table 3 Basic data to contextualise the mobilisable straw potential

\begin{tabular}{|c|c|c|c|c|}
\hline Baseline data & Min & Max & Unit & Source \\
\hline \multicolumn{5}{|l|}{ Biomethane production } \\
\hline Methane yield & 210 & 260 & $\mathrm{Lkg}_{\mathrm{vs}}{ }^{-1}$ & {$[58,59]$} \\
\hline Content of organic dry matter & 90 & 92 & $\%$ & {$[58,60]$} \\
\hline Dry matter content & 86 & 92 & $\%$ & {$[58,59]$} \\
\hline Methane content in biogas & 50.8 & 52.0 & $\%$ & {$[58,60]$} \\
\hline Biogas yield & 320.0 & 423.2 & $\mathrm{~L} \mathrm{~kg}_{\mathrm{fm}}{ }^{-1}$ & Calculated \\
\hline Lower heating value & 35.89 & & $\mathrm{MJ}\left(\mathrm{m}_{\mathrm{CH} 4}^{3}\right)^{-1}$ & {$[61]$} \\
\hline Overall efficiency biogas as fuel & 70 & 85 & $\%$ & {$[15]$} \\
\hline \multicolumn{5}{|l|}{ Emissions } \\
\hline Overall GHG mitigation potential & 60 & 85 & $\%$ & {$[15,62]$} \\
\hline Fossil fuel comparator (RED) & 94.0 & & $\mathrm{gCO}_{2}$-eq. $\mathrm{MJ}^{-1}$ & {$[11]$} \\
\hline \multicolumn{5}{|c|}{ TRL-9 plant for cereal straw mono-digestion } \\
\hline Straw demand & 40,000 & & Mg fm a ${ }^{-1}$ & {$[52]$} \\
\hline \multicolumn{5}{|c|}{ Energy demand in target markets 2014/2018 } \\
\hline Passenger cars & $1477 / 1481$ & & PJ & {$[63]$} \\
\hline Heavy goods traffic & $675 / 675$ & & & \\
\hline Bunkering seagoing vessels & $96 / 71$ & & & \\
\hline
\end{tabular}


having zero potential, which does not yet take into account whether they are balanced out by other regions. In the case of high raw material requirements, especially (e.g. in industrial hotspots), this can lead to considerable inaccuracies in assessing the national balance of supply and use. Moreover, assessments at the level of the administrative unit also neglect the spatial context of arable land distribution. To take these special features into account, the findings from Chapter 2.1 were transferred to a GIS. Connecting the data gathered on potential with a suitable geodata set enables a spatial analysis that is independent of administrative units.

The Federal Agency for Cartography and Geodesy (BKG) provides various nationwide geodata sets for this purpose [64]. The digital landscape models (DLMs) in the Authoritative Topographic-Cartographic Information System (ATKIS), e.g. Basis-DLM [65], DLM250 [66] or DLM1000 [67], include arable land under the "AX_Landwirtschaft" feature type, but are not freely available. In ALKIS [68], the Authoritative Real Estate Cadastre Information System, the "arable land" utilisation type is also available under "AX_TatsaechlicheNutzung", though it is only publicly available in a few federal states. CORINE Land Cover [69], by contrast, is a publicly available data set which is based on satellite data and covers arable land throughout Europe for the reference years 1990, 2000, 2006, 2012 and 2018. However, land use is generalised to 25 ha. A data set with 10 ha is available for 2018 [70], but the non-public ATKIS Basis-DLM data set [65] was nonetheless used for the analysis instead. With an area coverage from one hectare and an accuracy of one metre, this annually published geodata set offers the highest level of temporal and spatial detail. It does not, however, cover actual agricultural production. Under the law, this information is not in fact available in Germany [71]. The spatial analysis therefore follows the assumption that each polygon of arable land represents the statistical context of the associated NUTS-3 region. The steps set out in Fig. 2 were required to project the data onto the polygons of arable land.

The starting point is statistical data [37] on the acreage of all crops (A). This information was used to derive the percentages of the five cereal types in question (B). In connection with the polygons from the geodata set $(C)$, this generates the modelled cereal straw production area (D) for each polygon in a NUTS-3 region. In combination with the yield figures $(\mathrm{E})$ from the calculations of potential (Chapter 2.1), the area-related cereal straw potential is then derived for each polygon (F). For further data processing, the findings were converted into point data $(\mathrm{G})$; it was only at that juncture that they were linked to the location-specific information on industrial use $(\mathrm{H})$. The resulting data set (I) contains a full set of information on the mobilisable potential for the future production of biomethane in the form of a $1 \times 1 \mathrm{~km}$ raster. The spatial context was then evaluated by means of a neighbourhood analysis, distinguishing between catchment areas with radii of 20 and $50 \mathrm{~km}$ and adding the total amounts of raw material in each of the resulting areas to another raster data set (J, K). Finally, hotspot regions were identified by classifying the raw material requirements of the potential conversion plant.

\section{Results}

Temporal and spatial availability of cereal straw and biomethane

On national level (Fig. 3), in the years in question the theoretical and the technical potential of straw fluctuate

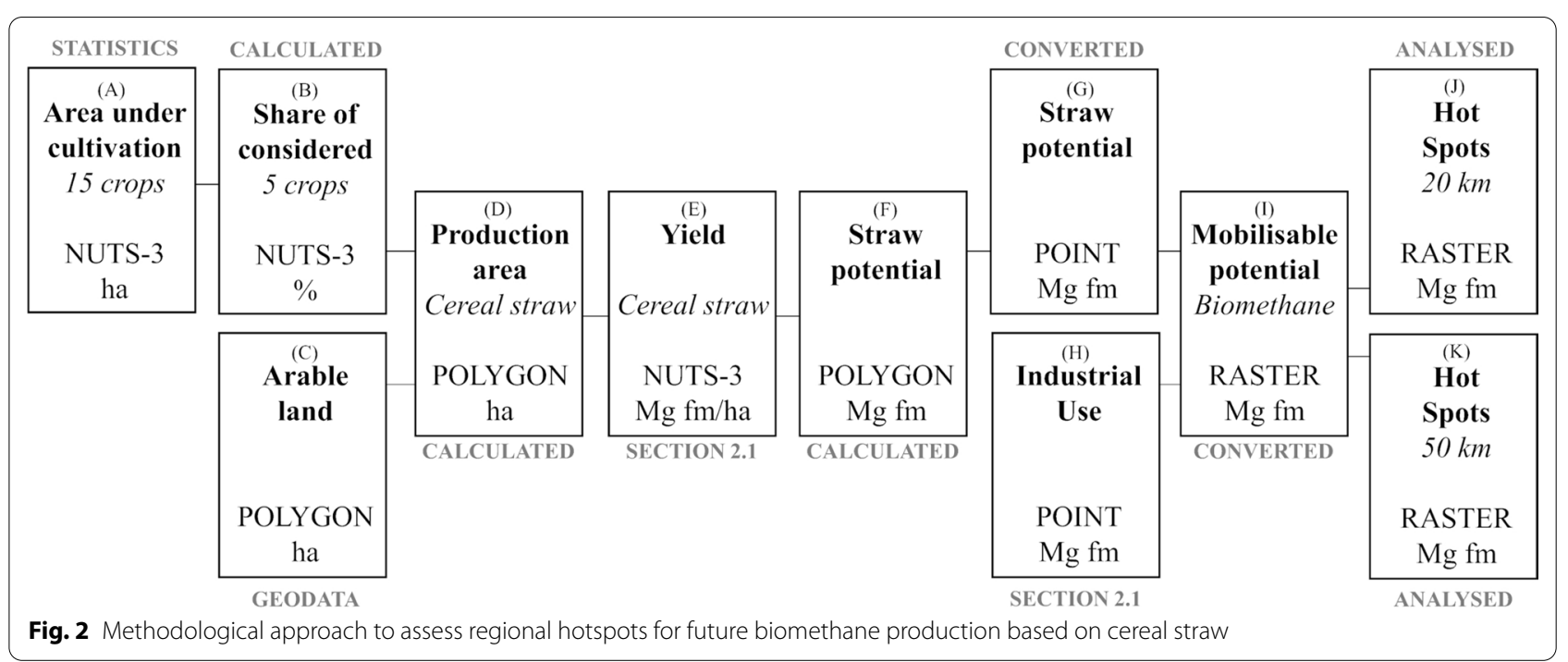




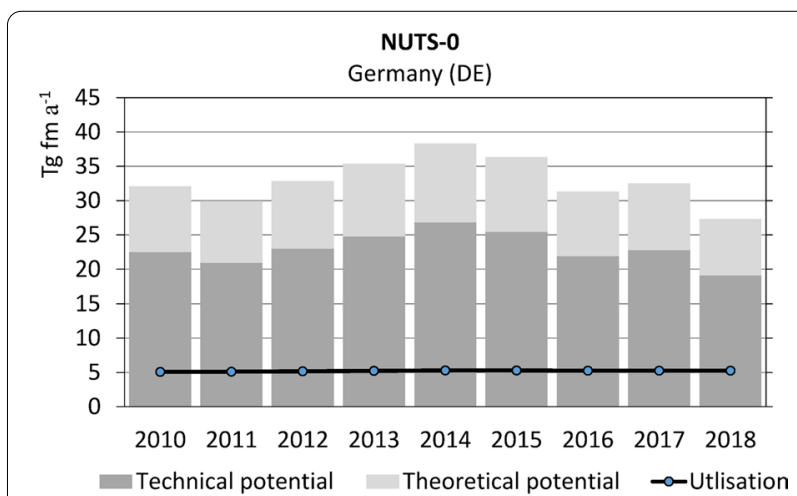

Fig. 3 Profile of biomass potentials and utilisation of cereal straw at national level, 2010-2018

between 27.3 and $38.3 \mathrm{Tg} \mathrm{fm} \mathrm{a}^{-1}$ and between 19.1 and $26.8 \mathrm{Tg} \mathrm{fm} \mathrm{a}^{-1}$, respectively. The maximum in 2014 and the minimum in 2018 are separated by just four years, but also a difference of up to $11 \mathrm{Tg} \mathrm{fm} \mathrm{a} \mathrm{f}^{-1}$, or $40 \%$. The use of cereal straw, however, exhibits no significant fluctuations. From 2010 to 2014 there is an increase $(+4.1 \%)$ followed by a slight decrease $(-0.9 \%)$. In 2018 , the level was $5.3 \mathrm{Tg} \mathrm{fm} \mathrm{a}{ }^{-1}$, i.e. $3.2 \%$ above that of 2010 . Due to the relatively constant level of use and the fluctuating supply of raw material, the share of the technical straw potential used ranges between a fifth (2014) and more than a quarter (2018).

The use is dominated by the amounts required for bedding and feed. The highest demand arises in 2018 for the husbandry of horses (41\%), pigs $(24 \%)$ and cattle (22\%). The remaining animals account for $8 \%$. Apart from livestock farming, the amounts required for special crops (2\%) and industrial use (2\%) take up a comparatively small share. One point that should be emphasised, however, is that industrial use increased 35 times from 2010 to around $114,000 \mathrm{Mg} \mathrm{a}^{-1}$ in 2018. This is mainly made up of incineration $(59 \%)$ and fermentation (35\%). The remaining $6 \%$ are other industrial uses. It should be taken into account that the primary data collection on industrial use is not claimed to be complete. In total, detailed information was collected on 12 plants. According to FNR [51], there are several decentralised, smaller plants in the incineration business on which no further information is publicly available. The number is expected to be in the double digits. Neither is there any information on the quantities or locations of straw used as a building material. Despite these uncertainties, on the national level it can be said that the amount of resources used was never higher than the amount supplied. This produces a range between 13.9 and $21.5 \mathrm{Tg} \mathrm{fm} \mathrm{a}^{-1}$ for the mobilisable straw potential. Compared to Weiser et al. [26] (see Chapter 1), this potential is at least $62 \%$ above the level discussed previously, as long as the straw is used in biogas plants including returning the digestate.

The regional availability of raw materials is influenced, among other things, by acreage, yield levels, and existing use. The maps in Fig. 4 show the spatial distribution of the technical potential (= raw material supply) including the trend compared to the previous year, raw material utilisation and the mobilisable potential (=availability). The years 2014 and 2018 were selected to illustrate the spatial range of the findings. Although these years are very close together, they are the all-time maximum (2014) and the minimum (2018) since 1994 (see Fig. 1).

The technical potential falls by almost eight million tonnes between 2014 and 2018. Nevertheless, in both years there are clear hotspots in the north (SchleswigHolstein, Mecklenburg-West Pomerania) and the east (parts of Brandenburg, Saxony, Saxony-Anhalt), along with certain regions in the west (on the border between Lower Saxony and North Rhine-Westphalia) and a few regions in southern Germany. A comparison of the two years shows a relatively high level of change in the regions in the far east (Brandenburg, eastern Saxony) and the far northwest (northern Lower Saxony). The 2017/2018 trend reveals significant losses ranging between over $20 \%$ and, sometimes, over $40 \%$ for these and numerous other areas. In contrast, the extreme west and south show some significant increases. The situation is contradictory for 2013/2014, with production significantly higher in 2014 than the previous year, 2013. Significant increases extend from the south across the east to the north. The level remained stable in the other regions. In contrast with this considerable dynamism, regional utilisation hardly shows any sign of change in the observation period. Consistently high utilisation rates can be seen for the northwest (western Lower Saxony, northern North Rhine-Westphalia), and utilisation is also comparatively high in the north (e.g. Mecklenburg-Western Pomerania, Prignitz, Uckermark) and certain regions in the south. On the one hand, this is due to the need for straw for livestock farming. On the other hand, especially in western Lower Saxony and Uckermark, there are industrial uses with a high straw requirement.

The mobilisable potential is the difference between the technical potential and utilisation. Compared with the technical potential, the situation is similar, but more nuanced. For example, the high utilisation rate in the northwest significantly reduces the potential that can still be mobilised there. In the weak year, 2018, the situation is similar for northern Lower Saxony, western Brandenburg and eastern Saxony-Anhalt. With regard to the mobilisable potential, the findings have a clear regional focus in eastern Schleswig-Holstein, throughout 

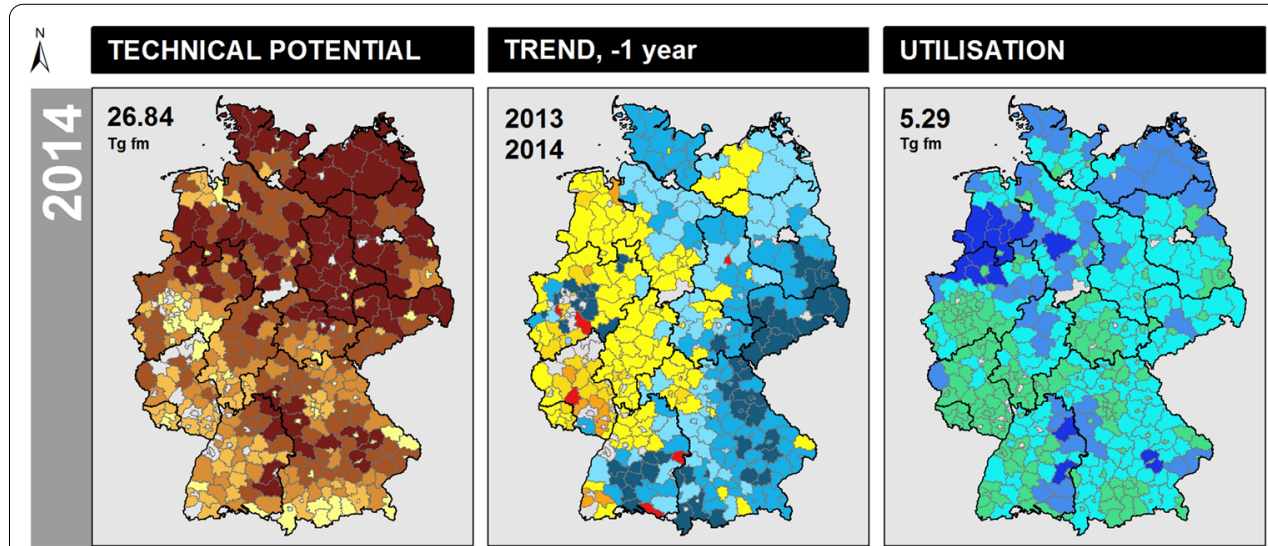

MOBILISABLE POTENTIAL
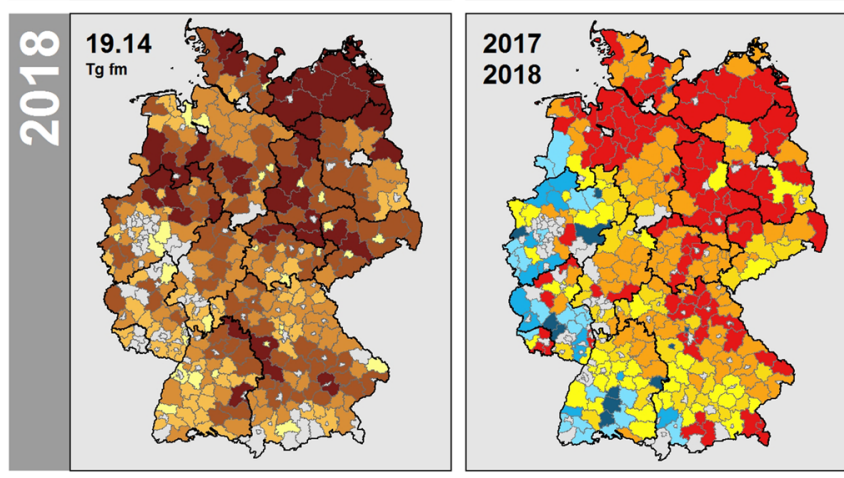

STRAW POTENTIALS

TREND

$\%$

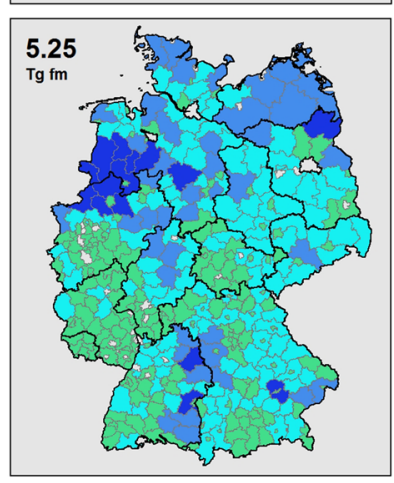

UTILISATION

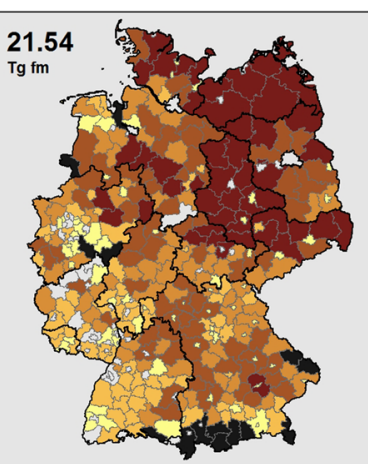

$\operatorname{Tg}$ fm

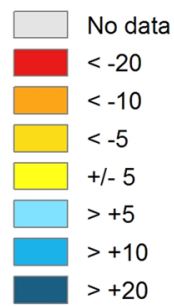

$\mathrm{Tg}$ fm

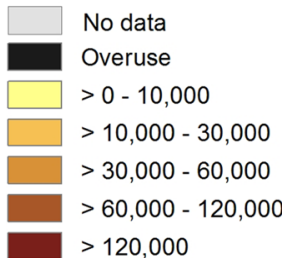

No data
-20
-10
-5
$>-5$
+5
+10
+20

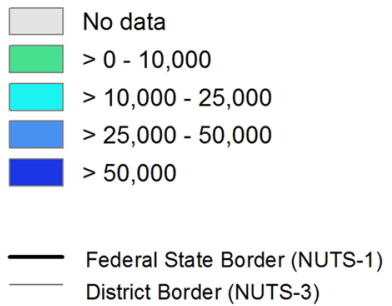

Fig. 4 Spatial distribution of technical straw potential, trend, utilisation and mobilisable straw potential at NUTS-3 level, 2014 and 2018

Mecklenburg-Western Pomerania, in Uckermark, central Saxony, western Saxony-Anhalt and southern Lower Saxony. Despite the higher use of raw materials and the strongly negative trend in 2018, these regions have a large mobilisable potential. In some regions, meanwhile, the amount used is higher than the supply, especially in the Alpine Foreland and a small number of regions in the northwest. The supra-regional situation is evaluated in Chapter 3.2. For some regions, it was not possible to generate any consistent data sets. For 2018, in particular there are a comparatively high number of gaps in the data, e.g. for the metropolitan regions in North Rhine-Westphalia.

To complement the maps, Fig. 5 summarises the quantitative distribution of the mobilisable potential for all
NUTS-3 regions. The primary axis shows the potential for each NUTS-3 region sorted in descending order. The secondary axis shows the cumulative potential as a biomass supply curve. In some hotspot regions, especially in Mecklenburg-Western Pomerania, the mobilisable potential is over $500,000 \mathrm{Mg} \mathrm{fm} \mathrm{a}^{-1}$ (2014) or over $300,000 \mathrm{Mg} \mathrm{fm} \mathrm{a}^{-1}$ (2018), respectively. This presentation of the findings shows that, of a total of 401 regions, a third of the total potential is concentrated in 27 (2014) and 30 (2018) regions. Two thirds of the potential are located in 88 (2014) and 92 (2018) regions.

Table 4 adds context to what these findings mean for the transport sector. It shows the number of possible plants of the selected plant concept (Chapter 2.1, Table 3), the potential amount of biomethane as fuel and 


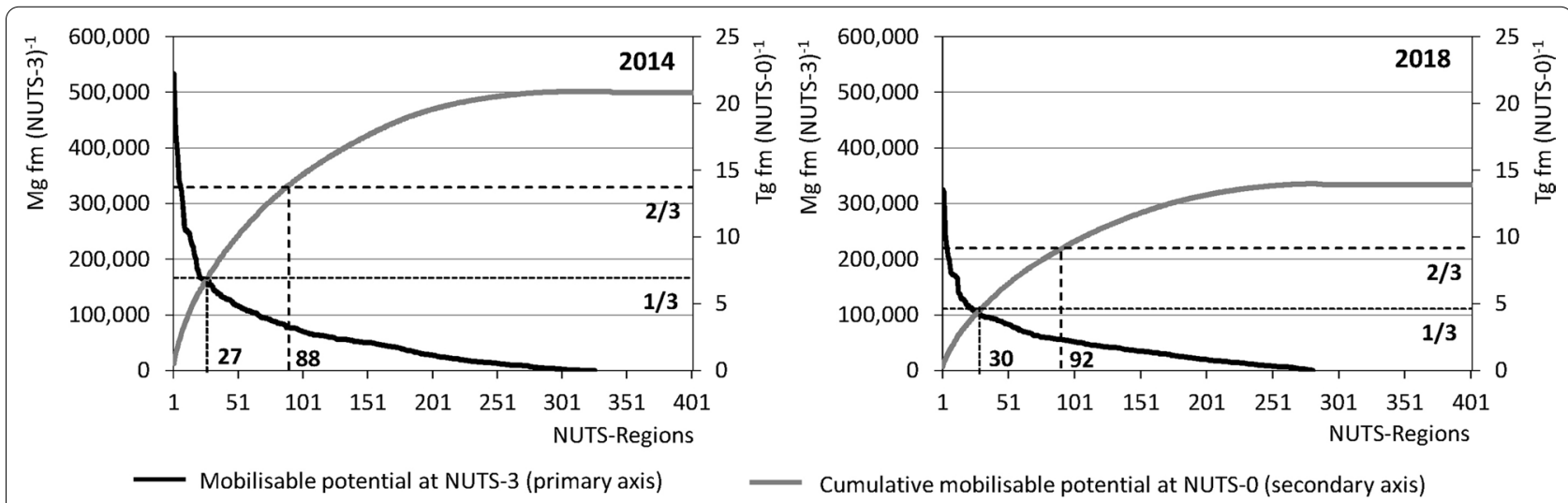

Fig. 5 Mobilisable potential for each NUTS-3 region sorted in descending order (primary axis) and cumulative mobilisable potential (secondary axis) in Germany, 2014 and 2018

two key figures for the selected transport modes passenger cars, heavy goods vehicles and maritime shipping. These relate to the possible GHG mitigation and the substitution of energy requirements in the target market when replacing fossil fuels. As it is unlikely that all the mobilisable potential will be fully tapped, a distinction is also made between the three levels of $66 \%, 33 \%$ and $10 \%$, which can be understood as farmers' willingness to supply straw. At the same time, this differentiation can also be interpreted as a reduction of the recovery rate from 70 to $46 \%, 23 \%$ and $7 \%$.

The differences in production levels for 2014 and 2018 show clear effects on the strategic relevance of biomethane in the transport sector. If the potential is fully tapped, from the point of view of resource availability, well over 300 plants could still be built even in weak years, and up to $7 \mathrm{Tg} \mathrm{CO}_{2}$-eq. avoided-in good years even up to 12 $\mathrm{Tg} \mathrm{CO}_{2}$-eq. With regard to achieving the climate target in the transport sector by 2030 (Chapter 1), this means making possible progress of up to $11-17 \%$ through the effective use of straw alone. However, if the minimum values are adopted, the share is more than halved to $5-8 \%$. In both considerations, the different straw availabilities during extreme years reduce the potential GHG mitigation by more than one third. Taking into account a reduced farmers' willingness to supply straw, the strategic relevance in terms of emissions reduction changes significantly. If only a third of the potential were tapped, well over 100 plants could still be built and in the best case 3-4 $\mathrm{Tg} \mathrm{CO} \mathrm{CO}_{2}$-eq. could be avoided. If, by contrast, only one in ten farmers made their straw available for future biomethane production, 35 plants could still be supplied. However, the use of straw could save not more than one million tonnes of $\mathrm{CO}_{2}$ equivalents, which is well below $2 \%$ of the sector's target. However, this level is higher than the GHG savings achieved in the entire transport sector since 1990. Especially in the case of a higher utilisation rate of cereal straw, there are promising opportunities to realise a significant contribution to GHG mitigation.

With regard to the substitution potential for fossil fuels, considerable differences can be identified for the respective modes of transport. Due to the different energy requirements and taking into account the optimum case, the demand for bunkering seagoing vessels could be met in full. Up to a fifth could be substituted for HGVs and up to a tenth of passenger cars could be supplied with a low-emission fuel. If only a third of the mobilisable straw potential was provided as biomethane in the transport sector, the shares would decrease to $7 \%$ and $3 \%$, respectively. The shipping sector would still achieve around half. If only $10 \%$ of the potential would be utilised, the share for HGVs and passenger cars is in almost all cases well below one percent and between 13 and 15\% for the shipping sector.

\section{Hotspots for future biomethane production}

In some regions, meanwhile, the amount of raw materials used is higher than the supply. Figure 6 shows the findings for two selected examples as a graph. In the first region, "Grafschaft Bentheim" (western Lower Saxony), Germany's first plant designed for the industrial use of cereal straw entered operation in 2014. As a result, the use of straw has tripled to over $90,000 \mathrm{Mg} \mathrm{a}^{-1}$ and will significantly exceed the local raw material supply this year. Meanwhile, in the second example "Rosenheim, Landkreis" (Alpine Foreland), straw use is entirely related to livestock farming. The high demand has to be balanced out by other regions, which cannot be assessed at the level of the administrative unit (Fig. 4).

The spatial links between the supply of resources and their use were therefore analysed using a GIS. The results 


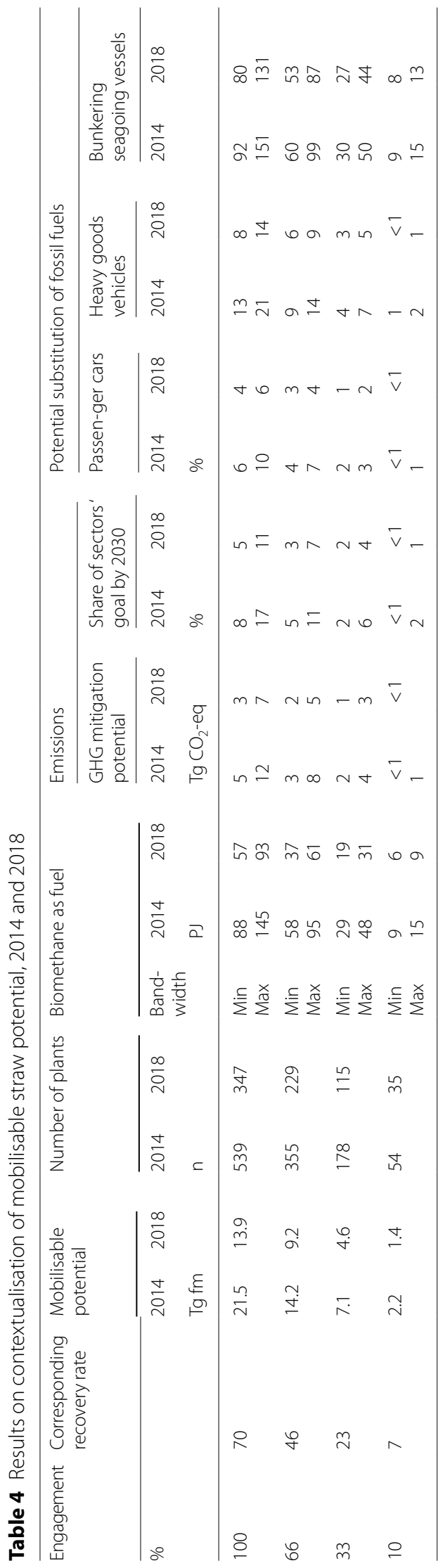




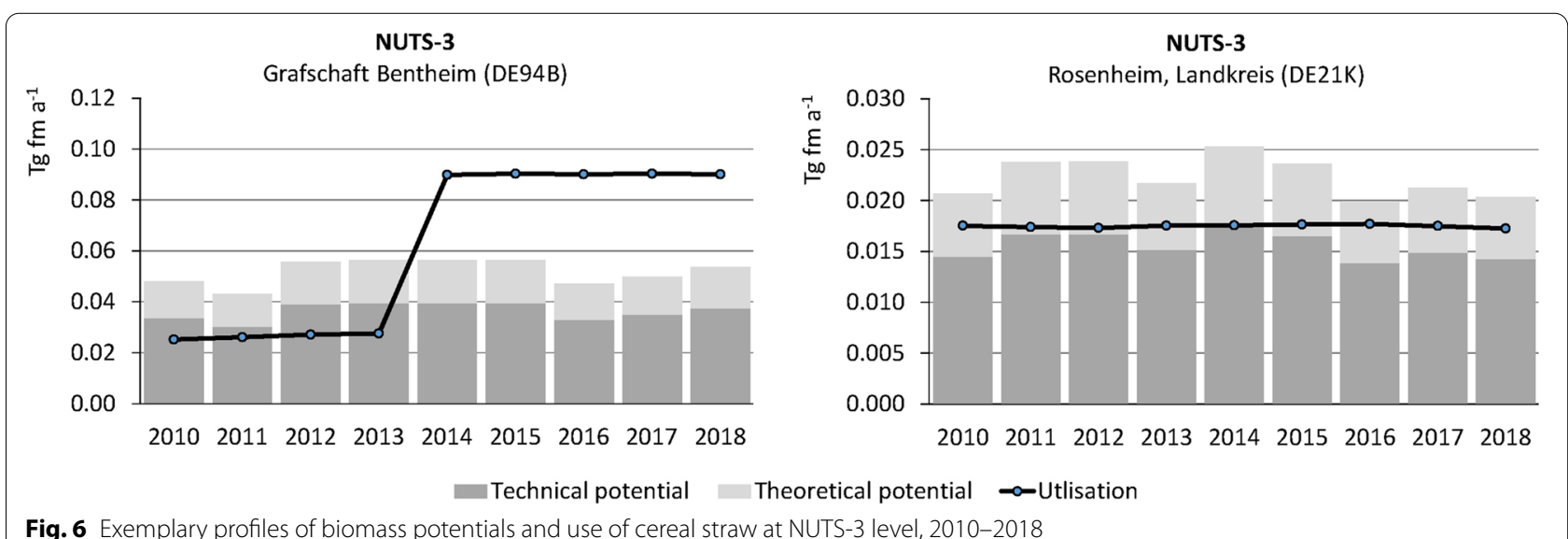

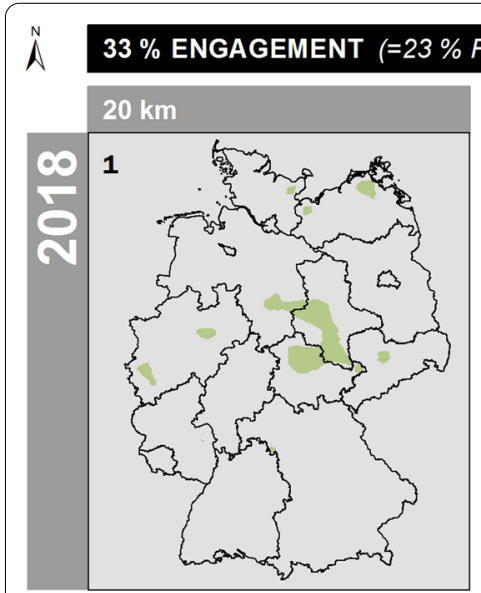

\section{ECOVERY RATE)}
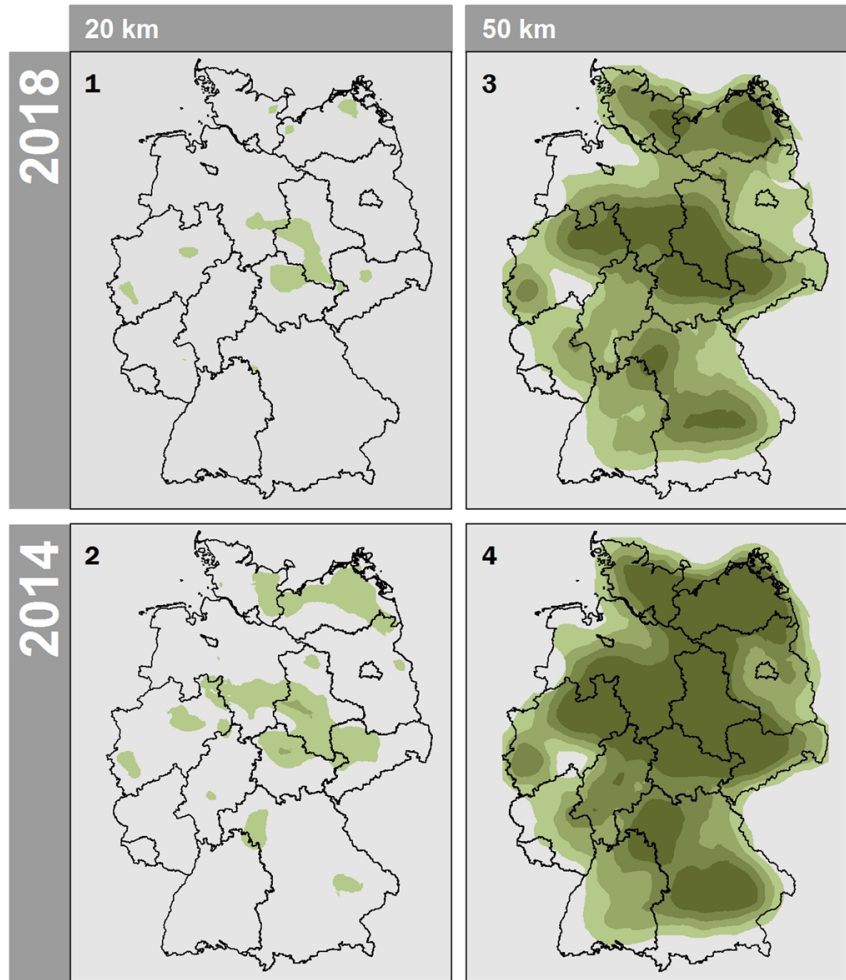

3 plants

4 and more plants
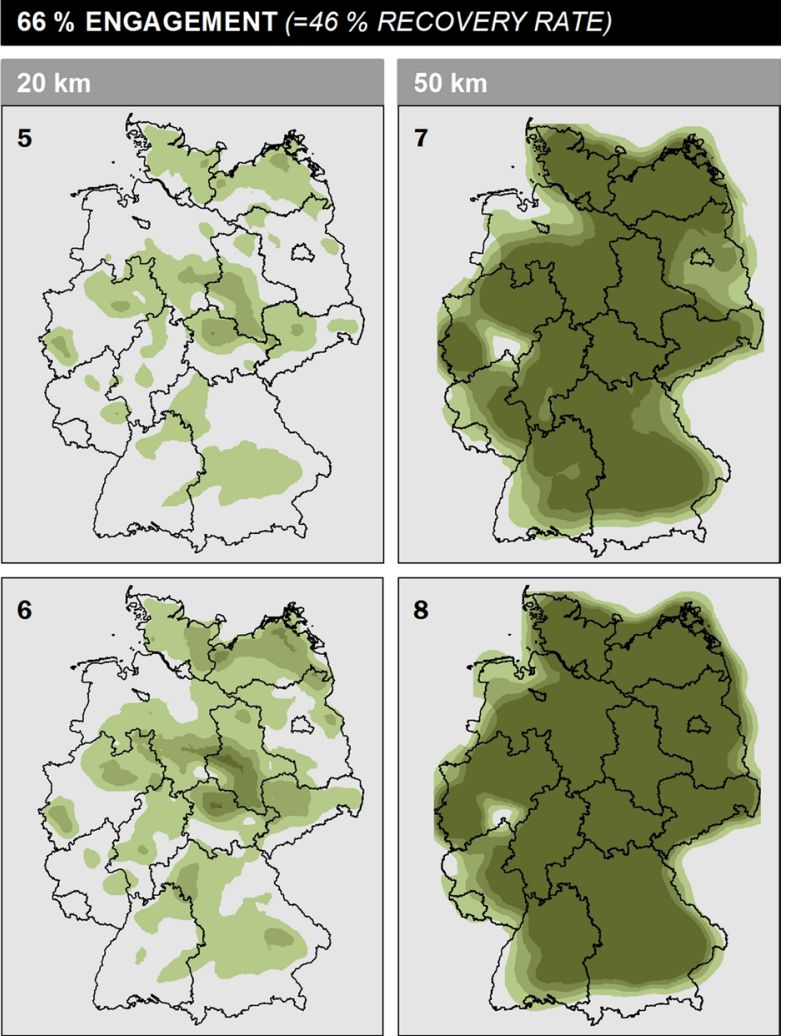

$0 \quad 100 \quad 200 \mathrm{~km}$

Fig. 7 Hotspot regions with mobilisable potential $>40,000 \mathrm{Mg}$ fm incl. $33 \%$ and $66 \%$ engagement or $23 \%$ and $46 \%$ recovery rate and catchment area radii of 20 and $50 \mathrm{~km}, 2014$ and 2018

generated take into account both cross-regional compensation for deficits and the regional importance of multiple small neighbouring regions that can be viewed as a network. On this basis, options for the future use of raw materials can be evaluated on a plant-specific basis. In combination with the catchment areas with radii of
20 and $50 \mathrm{~km}$, Fig. 7 shows the areas in which a plant requirement of $40,000 \mathrm{Mg} \mathrm{a}^{-1}$ (Chapter 2.1, Table 3) can be met either fully or multiple times. In line with Table 4 , the spatial context is also shown in the case of a willingness to supply straw of $33 \%$ and $66 \%$ or a recovery rate of $23 \%$ and $46 \%$, respectively. 
A low willingness to supply straw (33\%) and a low transport distance $(20 \mathrm{~km})$ set high requirements and generate clearly delineated hotspot regions. In the weak year of 2018 (Map 1), the hotspots run through the fertile Börde lowlands from west to east, from the JülichZülpich Börde west of Cologne, via the Warburg Börde north of Kassel to the Hildesheim Börde south of Hanover, the Magdeburg Börde and the Thuringian Basin. In the strong year of 2014 (Map 2), these regions expand, forming a ribbon extending from west Saxony to North Rhine-Westphalia. In the east of Schleswig-Holstein, the north of Mecklenburg-Western Pomerania, parts of Brandenburg (Uckermark, Oderbruch), around Würzburg and south of Regensburg, there are also very good conditions for a supply of raw material. As these are classic wheat-growing areas with fertile soils, out of all regions they pose the lowest risk of a lack of raw materials. At the same time, the digestate would not have to be transported long distances for spreading. If it is transported over longer distances, the raw material can be supplied almost anywhere. With a catchment area radius of up to $50 \mathrm{~km}$ (Maps 3 and 4), plants could be built all over Germany, at least from the point of view of resource availability. The only exceptions are the north and west of Lower Saxony, the Black Forest and the Alpine Foreland, as use in these areas is already relatively high and there is little or no cereal cultivation in those areas. The area in the south of North Rhine-Westphalia is not a gap in the data, but a densely forested mountainous region (the Taunus range). If there is greater willingness to supply straw (66\%), the hotspots expand accordingly. Above all, large parts of Bavaria and Hesse also emerge as priority areas (Maps 5 and 6). With a larger catchment area radius, sufficient amounts of raw material can be tapped across the country to operate more or larger plants (Maps 7 and 8). In summary, it can be said that the spatial precision of the findings in Chapter 3.1 can be improved using GIS analysis. This considerably adds to the range of possible interpretations regarding the replication of the plant concept under consideration.

\section{Discussion}

Previous studies assume that the future increased industrial use of straw would result in a removal rate that has a negative impact on the humus content. However, the humus and nutrient balance can be positively influenced by biochemical conversion, including returning the digestate to the farmland. Initial field tests show interesting results, though these are not enough for a long-term evaluation. Moreover, as the soil characteristics, soil management and weather are subject to wide regional variation, the results of individual tests cannot be generalised or easily transferred to the country as a whole.
Furthermore, the humus and nutrient balance is not the only important parameter for the evaluation of ecological sustainability. The use of straw may also influence numerous other functions such as water balance, weed suppression or feed for soil animals. The impacts on the overall soil quality and biodiversity have not yet been sufficiently considered in any study available. For this reason, the calculations presented are based on the central assumption of a limited straw recovery, resulting in a total of $70 \%$ going into potential circular economy. This approach can be discussed as controversial, because there are considerable uncertainties in determining sustainable recovery rates. To describe the effects of a reduced recovery, different mobilisation and corresponding recovery rates down to $7 \%$ were evaluated to cover a wide range of conceivable options. However, the aim of the analyses was to examine the possible strategic relevance in the transport sector of biomethane produced from straw under these conditions. It is thus more a question of whether it is worth looking into the topic in further detail. The answer is a clear "yes". The straw potential calculated is in the best case $65 \%$ above the previously known level for this field of application, published by Weiser et al. [26] in 2014. However, the two approaches cannot be compared methodologically. The authors' extensive assessment of the carbon balance was geared towards the removal of straw, and did not take into account the possibility of digestate being returned to the farmland. The result of 8.0 to $13.3 \mathrm{Tg} \mathrm{fm} \mathrm{a}{ }^{-1}$ also was based on the average values for 1999, 2003 and 2007. Extreme values in individual years (see Figs. 1, 3) differ significantly from the average and have a significant impact on the amounts that can be mobilised each year. There are thus not enough existing source data to be able to adequately assess the options for biomethane produced from straw, so way in which the specifics of the material flow relate to the straw potential must be assessed individually for each type of use.

Using the new findings, it will be possible to develop a better description of the risks jeopardising resource availability across different times and regions, making it possible to scale up the selected technology. In this context, the results can also be used for evaluating other plant sizes or applications (e.g. heat generation, material use of gases). Particularly suitable regions can be identified for the future mobilisation of raw materials. On this basis, the focus can be placed on the further analysis of regional stakeholder and shareholder relationships. According to Pfeiffer et al. [72], farmers' willingness to supply straw is the key prerequisite for its successful mobilisation as a raw material. It would thus be an important next step to discuss the results of the calculations with farmers in hotspot regions and compare theory with practice. Further aspects that have not yet been taken into account 
(e.g. further competitive uses) could be jointly identified and included in future evaluations. A major challenge, for example, is also the return of the digestate that must be brought back to exactly the same area from which the straw was taken. In practice, this is not possible. One thinkable option could be the introduction of certified quality standards, which would make it easier to manage regional differences. Until now, it has only been possible to make a rough estimate of the actual mobilisable potential of straw, as it depends upon decisions made by individuals. However, the findings show that even a low take-up of just $10 \%$ could generate significant amounts of low-emission fuels. If it is possible to create a favourable situation with respect to all the stakeholders in the hotspot regions, a promising step on the path to sustainable mobility could be taken well before 2030 .

The calculations presented here are based on numerous data sources of heterogeneous temporal and spatial quality. The weighted distribution of some livestock figures from NUTS-1 to NUTS-3 level is associated with a high level of uncertainty. Horses, for example, make up the highest share of straw use at $41 \%$, but official statistics are incomplete; the large number of horses is based on one literature source for a single year. The straw requirement for ducks, geese, turkeys and goats is also weighted, and is comparatively low at less than $8 \%$. By contrast, there is plenty of data on cattle and pigs (together approx. 46\%). Regional peculiarities and competing uses can nonetheless only be mapped in general, in part due to the data on husbandry. This information is only available for 2010 and only at NUTS-1 level. As some data is unavailable, structural changes over time or regional hotspots where several animal species are housed on straw can only be reflected to a limited extent in the analysis. Thus, due to insufficient databases, it is not yet possible to differentiate between conventional and organic farming, neither for animal husbandry nor the calculation of straw potentials. The statistical source data will not be updated until the agricultural census in 2020 [73].

Another subject in the discussion on data quality is differences in the regional levels used in official statistics. The sum of the NUTS-3 regions does not necessarily equal the value of the higher level. Missing or inconsistent data sets create gaps in the data. This may lead to incomplete statements, especially with GIS-based analyses. The assumption that each individual polygon of arable land reflects the statistical situation of the associated NUTS-3 region is also a means of linking in with the spatial distribution of arable land, but cannot model actual cultivation. Information on actual annual cultivation is not available for reasons of data protection. Generalising the spatial information to a $\mathrm{km}^{2}$ raster makes it sufficiently non-specific while still allowing hotspot regions to be identified.

The focus of this work was exclusively on Germany. However, the regional availability of resources does not end at national borders. Considerable regional synergies can be expected, especially in the regions bordering Poland (e.g. south of Szczecin). Transnational analyses (e.g. [27, 28]) offer evidence of this, but the resources have not yet been evaluated in detail over the course of time. With regard to extreme weather events, temporally and spatially detailed information on the availability of resources is becoming increasingly relevant as a better means of evaluating the considerable fluctuations and their possible effects. On this basis, it is possible to quantify the chances of scaling a technology until it becomes strategically relevant for society's goals (e.g. GHG mitigation in the transport sector, level of substitution in target markets). One important prerequisite for an assessment of this kind is that the basic data are consistent from one study to the next. Differences and sensitivities in basic calculation values can lead to considerable deviations in results even if the actual calculation method used is the same. These include, for example, grain-straw ratios, the amount of organic dry matter, the water content or animal-specific bedding requirements. Methane yields and emission factors have a particularly great influence on the strategic relevance of biomethane, for example. Under laboratory conditions, up to $70 \%$ higher methane yields are achieved (e.g. $[74,75])$ than those published in the general, basic literature (e.g. [58]). In practice, higher methane yields lead to higher levels of substitution in the target markets and also to higher GHG savings. In this work, GHG emissions were only roughly estimated by relatively high bandwidths. However, it is still possible to determine the level of a potential contribution to the transport sector. Detailed, plant-specific LCAs can be used in future to find out at which end of the bandwidth an actual contribution can be expected. For fruitful discussion on these subjects, the basic data need to be constantly reviewed and information urgently needs to be shared among all the stakeholders involved. This, in turn, relies upon a high degree of transparency.

\section{Conclusion}

The present work complements Germany's national residue monitoring and offers a detailed insight into the temporal and spatial dynamics of straw availability from 2010 to 2018. Despite the marked fluctuations and the extreme years of 2014 and 2018, an efficient cascade use of straw could achieve relevant shares of the GHG reduction target in the transport sector. However, the strategic contribution depends very much on the mobilisation rate of cereal straw. Taking various scenarios into account, 
the results show a high bandwidth of less than one and up to $17 \%$ of the sector's target. With regard to the substitution of fossil fuels, there are advantages in the context of maritime shipping. It has much greater potential as an alternative means of providing the energy required to bunker seagoing vessels than for heavy goods vehicle or passenger car traffic. In ideal conditions, the energy requirement could be covered completely, and even under restricted conditions, including a mobilisation rate of one third, up to $50 \%$ could still be achieved. In heavy goods vehicle and passenger car traffic, only seven and three percent, respectively, can be replaced in the same context. However, the overall contribution to the sector remains the same and in which modes of transport biomethane could be used and would make sense depends on numerous factors. This includes, for example, details of existing or future fuel distribution and filling infrastructures. Major challenges exist especially in engine technology in connection with the methane slip [16]. Leaking methane would have a significant negative impact on the GHG balance. To successfully replicate the plant concept under consideration, numerous additional background circumstances must be taken into account. This involves, among other things, the infrastructure for grid injection and transmission, demand in the target market, legal framework and, in particular, the corresponding economic efficiency. Yet the central prerequisite for successful mobilising straw as a raw material is for an understanding to be reached between regional stakeholders in the fields of agriculture, business, politics, science and society. Without a broad consensus, the importance and impact of biomethane in the transport sector is likely to remain low. Exchanging and disclosing basic data could support discussion among these groups and encourage them to prioritise the next steps to be taken. This could be a means of overcoming reservations and pinpointing commonalities. There is also a particular need for research in connection with sustainable recovery rates and the associated effects on soil quality. One important element in this process is providing open access to the data generated so that the calculations can be individually assessed and continuously improved towards more ecological sustainability. For this reason, the findings will be transferred in full to the DBFZ resource database, which was set up at http://webapp.dbfz.de as part of the national residue monitoring system and can be accessed free of charge in the long term. At the same time, information on the methodological approaches, the background knowledge and the contextualisation used to calculate the potential will be conveyed in e-learning units [76]. This will include practical examples to extend university education of how to deal with open-access data.

An important subsequent step would be regular temporal and spatial assessments of the balance between the supply and use of other important digestible biomass types. In rural contexts, this affects not only straw from the field, but also solid manure as part of straw use and slurry. In urban contexts, the focus is on sewage sludge and organic and green waste. One aspect which could be of particular importance might be identifying regional synergies between different material flows and existing plant capacities. This could be a means of providing an additional, significant amount of biomethane. At the end of 2019, the second large-scale industrial plant for straw mono-digestion went into operation. With the potential presented and the hotspots identified, clear recommendations emerge where future resource mobilisation could be promising.

\section{Appendix}

See Table 5. 
$\stackrel{\Xi}{\Perp}$

芩

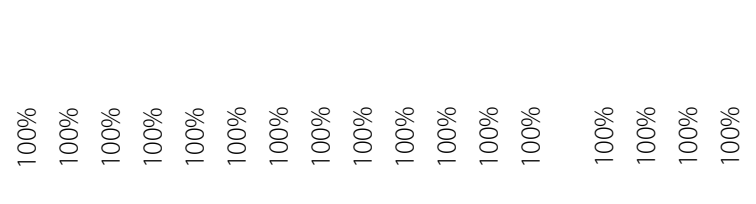

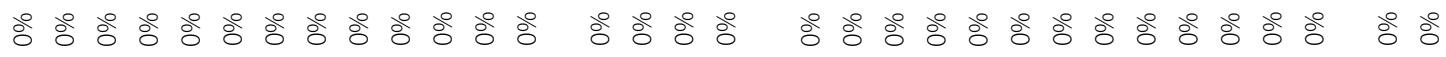
ơ

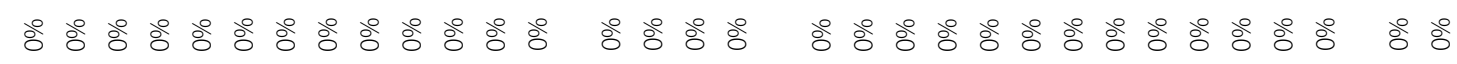

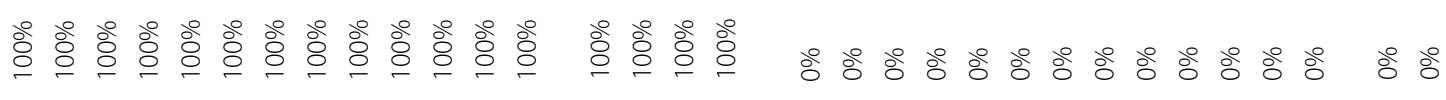
Th

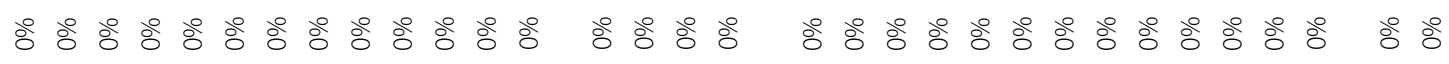

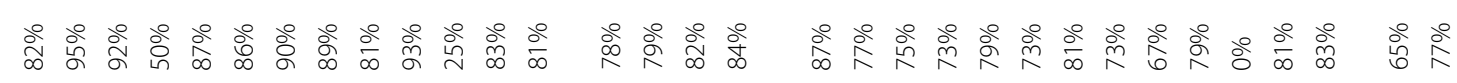

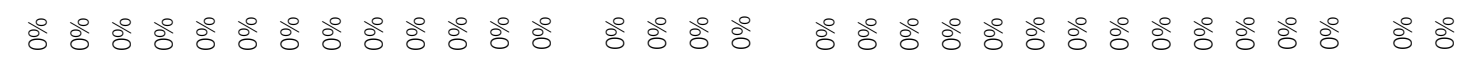

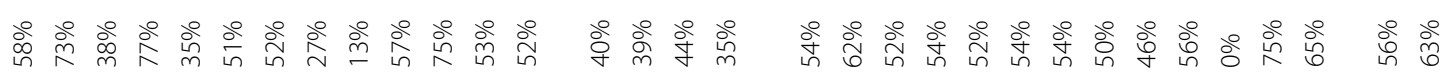

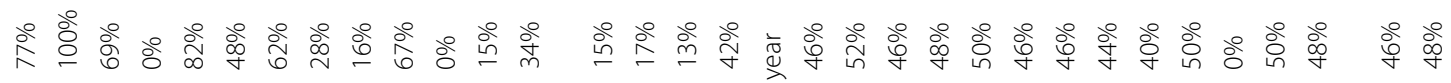




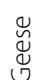

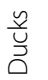

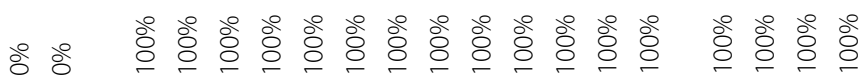

产

荇

苑

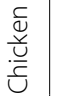

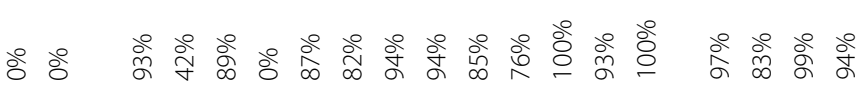

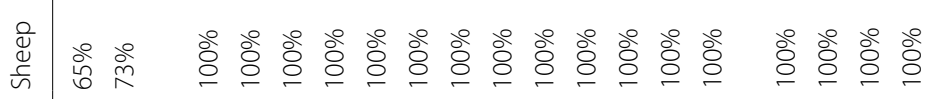

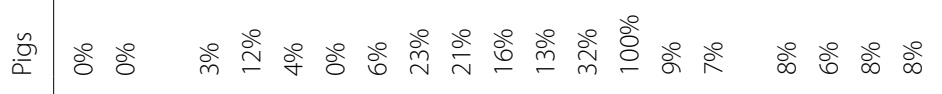

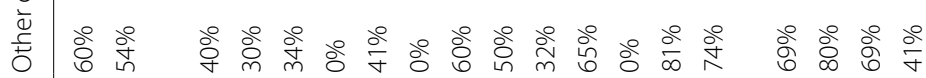
ஓे

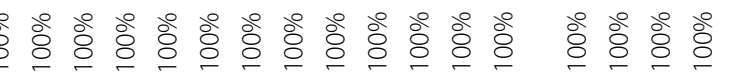

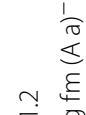

$\overline{=}$

总总总总总总总

$\stackrel{5}{\xi}$

$\sim \stackrel{9}{9}$

i

है

$\wedge$ 모․

$\frac{1}{8}$

ह

$0 \stackrel{9}{9}$

峞总点总总总总总

5
o
s
$\xi$

ㄴ.

$\hat{m} \hat{m} \hat{m} \hat{m} \hat{m} \hat{m} \hat{m}$

T

1
0
0
8
8
ह
है
है

ते है Tิ

है वे

용.

Tิ

全

$\circ$ ह

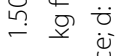
Tे $\frac{\pi}{0}$ \& है 万ิ 这点

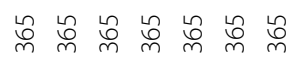
ช্ণ

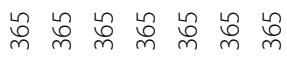

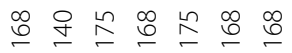
○晨

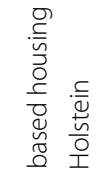
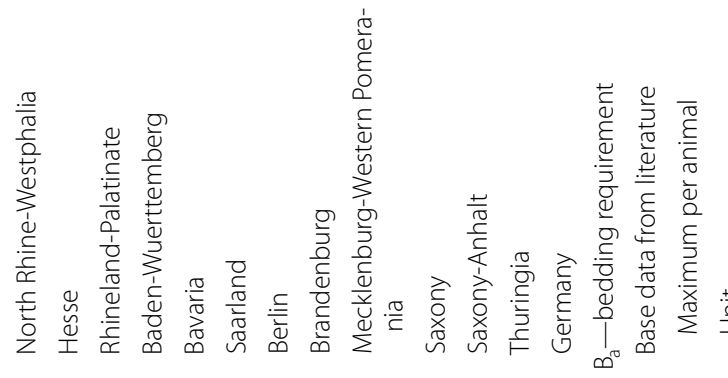

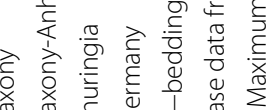

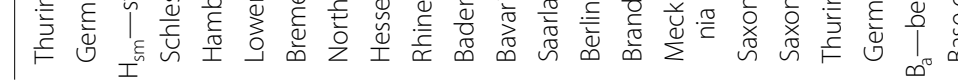


$\stackrel{凶}{\varpi}$

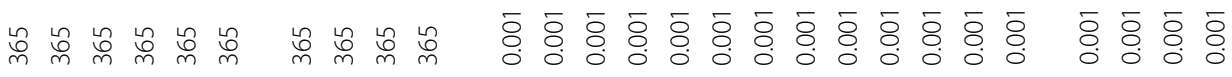

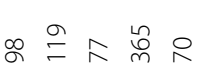

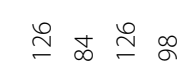

ֻे.

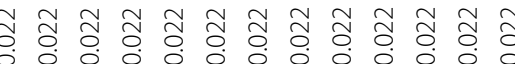

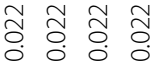

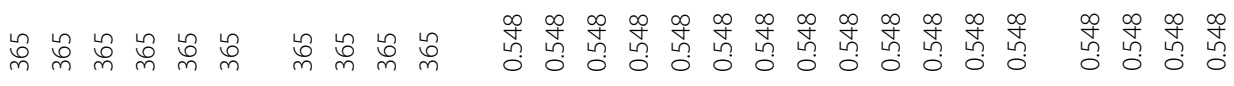

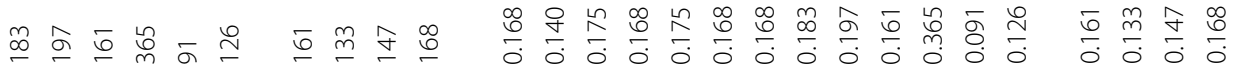

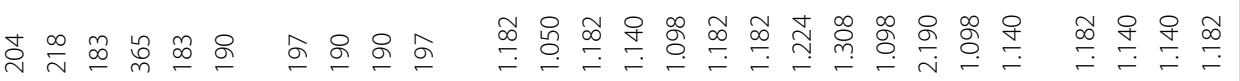

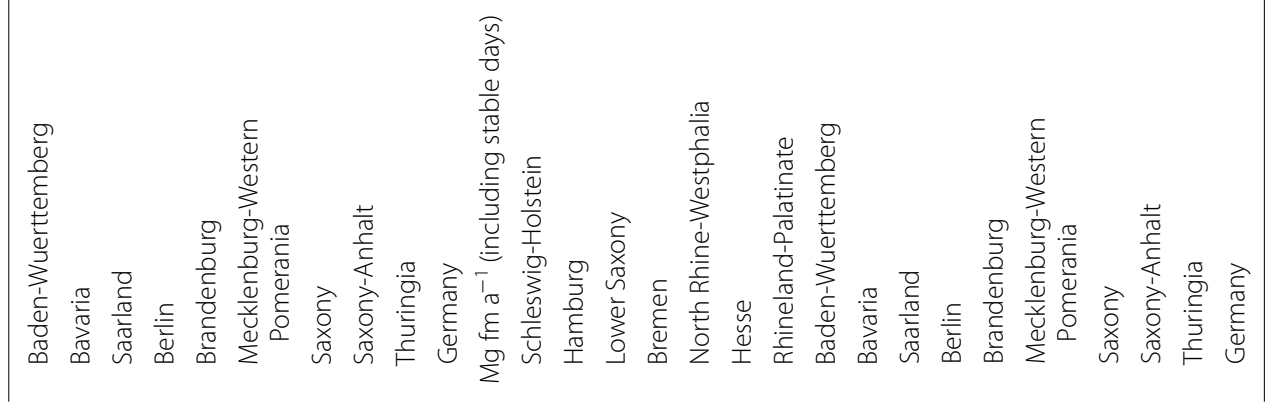




\begin{abstract}
Abbreviations
CNG: Compressed natural gas; DLM: Digital Landscape Model; FM: Fresh matter; GHG: Greenhouse gas; GIS: Geo-Information System; HGV: Heavy goods vehicle; LCA: Lifecycle assessment; LNG: Liquefied natural gas; NUTS: Nomenclature des unités territoriales statistiques; RED: Renewable Energy Directive; TRL:Technology readiness level; UN: United Nations; VS: Volatile solids.
\end{abstract}

\section{Acknowledgements}

The authors thank the Federal Agency for Cartography and Geodesy (BKG) for providing the geodata, and Vereinigte Bioenergie GmbH (VERBIO) and Stefan Majer (DBFZ) for the friendly sharing of knowledge.

\section{Authors' contributions}

$A B$ designed the analysis, collected the literature, processed the data and wrote the manuscript. RB and DT supervised the research and supplemented parts of the manuscript. All authors read and approved the final manuscript.

\section{Funding}

Open Access funding enabled and organized by Projekt DEAL. These findings were gathered as part of the "Pilot plant for synthetic biogas (Pilot SBG)" project, commissioned by the Federal Ministry of Transport and Digital Infrastructure (BMVI). The authors would also like to thank the BMVI for funding the "OpenGeoEdu" project, part of the mFUND programme (Funding no./FZK: 19F2007A).

\section{Availability of data and materials}

The compiled data will be publicly available at DBFZ Resource Database following http://webapp.dbfz.de.

\section{Ethics approval and consent to participate}

Not applicable.

\section{Consent for publication}

Not applicable.

\section{Competing interests}

The authors declare that they have no competing interests.

\section{Author details}

1 Deutsches Biomasseforschungszentrum Gemeinnützige GmbH, Torgauer Str. 116, 04347 Leipzig, Germany. ${ }^{2}$ Faculty of Economics and Management Science, Leipzig University, Grimmaische Str. 12, 04109 Leipzig, Germany.

${ }^{3}$ Faculty of Agricultural and Environmental Science, University of Rostock, Justus-von-Liebig-Weg 6, 18059 Rostock, Germany. ${ }^{4}$ Helmholtz Centre for Environmental Research - UFZ, Permoserstr. 15, 04318 Leipzig, Germany.

Received: 25 February 2020 Accepted: 24 November 2020

Published online: 21 December 2020

\section{References}

1. Leyen $U$ von der. Turning challenge into opportunity on the course to becoming the first climate-neutral continent: Press release. https://ec. europa.eu/commission/presscorner/detail/en/AC_19_6778. Accessed 20 Jan 2020

2. German Environment Agency (UBA). Climate Protection Goals in Germany. https://www.umweltbundesamt.de/daten/Klima/Klimaschutzzieledeutschlands. Accessed 20 Jan 2020

3. Federal Ministry for the Environment, Nature Conservation and Nuclear Safety. Climate Action Plan 2050 - Germany's long-term emission development strategy. https://www.bmu.de/en/topics/climate-energy/ climate/national-climate-policy/greenhouse-gas-neutral-germany-2050/. Accessed 20 Jan 2020

4. The Federal Government. Climate Protection Act and amending other regulations: KSG; 2019

5. German Environment Agency (UBA). GHG Mitigation Goals Germany: Provision of annual raw data as xls. https://www.umweltbundesamt.de/
daten/Klima/treibhausgasminderungsziele-deutschlands. Accessed 19 June 2020

6. Lenz B, Aigner M, Baumann E, Moctar BOe, Hauptmeier K, Kaltschmitt M et al. Electromobility, Fuel Cell, Alternative Fuels - Application Options from Technological Perspective: Working Group 2 "Alternative Engines and Fuels for Sustainable Mobility. National Platform for Future Mobility (NPM). https://www.plattform-zukunft-mobilitaet.de/wp-content/uploa ds/2019/11/NPM_Bericht_AG2_112019_Web.pdf. Accessed 20 Jan 2020

7. Meisel K, Millinger M, Naumann K, Müller-Langer F, Majer S, Thrän D (2020) Future renewable fuel mixes in transport in Germany under red ii and climate protection targets. Energies 13(7):1712

8. Millinger M, Meisel K, Thrän D (2019) Greenhouse gas abatement optimal deployment of biofuels from crops in Germany. Transport Res D 69:265-275

9. Millinger M, Meisel K, Budzinski M, Thrän D (2018) Relative greenhouse gas abatement cost competitiveness of biofuels in Germany. Energies 11(3):615

10. Thrän D, Schaubach K, Majer S, Horschig T (2020) Governance of sustainability in the German biogas sector-adaptive management of the Renewable Energy Act between agriculture and the energy sector. Energy Sustain Soc 10(1):477

11. European Parliament, Council of the European Union. DIRECTIVE (EU) 2018/2001 OF THE EUROPEAN PARLIAMENT AND OF THE COUNCIL of 11 December 2018 on the promotion of the use of energy from renewable sources (recast); 2018

12. Federal Ministry of Education and Research (BMBF), Federal Ministry of Food and Agriculture (BMEL). National Bioeconomy Strategy: Summary. https://www.bmbf.de/files/neue\%20nationale\%20bio\%c3\%b6konomies trategie.pdf. Accessed 27 Jan 2020

13. Brosowski A, Krause T, Mantau U, Mahro B, Noke A, Richter F et al (2019) How to measure the impact of biogenic residues, wastes and byproducts: development of a national resource monitoring based on the example of Germany. Biomass Bioenergy 127:105275

14. Deutsches Biomasseforschungszentrum gemeinnützige $\mathrm{GmbH}$ (DBFZ). DBFZ - Resource Database: Stand am 27.01.2020. http://webapp.dbfz.de/ resources. Accessed 27 Jan 2020

15. Scholwin F, Grope J, Clinkscales A, Boshell F, Saygin D, Salgado A et al. Biogas for road vehicles: Technology brief. https://www.irena.org/-/ media/Files/IRENA/Agency/Publication/2017/Mar/IRENA_Biogas_for_ Road_Vehicles_2017.pdf. Accessed 18 June 2020

16. Lowell $D$, Wang H, Lutsey N. Assessment of the fuel cycle impact of liquefied natural gas as used in international shipping: White paper. https:// theicct.org/sites/default/files/publications/ICCTwhitepaper_MarineLNG_ 130513.pdf. Accessed 19 June 2020

17. Edel M, Jegal J, Siegemund S, Schmidt P, Weindorf W. Bio-LNG - a renewable and low-emission alternative in the road freight and water transport: Potentials, economic efficiency and instruments. https://www.dena.de/ fileadmin/dena/Publikationen/PDFs/2019/dena-Studie_Bio_LNG.pdf. Accessed 28 Jan 2020

18. Federal Ministry of Food and Agriculture (BMEL). Harvest 2019: Quantities and Prices. https://www.bmel.de/SharedDocs/Downloads/Landw irtschaft/Markt-Statistik/Ernte2019Bericht.pdf?_blob=publicationFile. Accessed 23 Feb 2020

19. Food and Agriculture Organization (FAO). Crop production in Germany 1961-2017: Area harvested, yield and production quantity on wheat, rye, barley, oats, triticale. http://www.fao.org/faostat/en/\#data/QC. Accessed 27 Jan 2020.

20. German Weather Service (DWD). German Climate Atlas: Anomalies in Precipitation 2002. https://www.dwd.de/EN/climate_environment/clima teatlas/climateatlas_node.html. Accessed 30 Jan 2020

21. German Weather Service (DWD). German Climate Atlas: Anomalies in Precipitation 2003. https://www.dwd.de/EN/climate_environment/clima teatlas/climateatlas_node.html. Accessed 30 Jan 2020

22. German Weather Service (DWD). German Climate Atlas: Anomalies in Precipitation 2007. https://www.dwd.de/EN/climate_environment/clima teatlas/climateatlas_node.html. Accessed 30 Jan 2020.

23. German Weather Service (DWD). German Climate Atlas: Anomalies in Precipitation 2011. https://www.dwd.de/EN/climate_environment/clima teatlas/climateatlas_node.html. Accessed 30 Jan 2020. 
24. German Weather Service (DWD). German Climate Atlas: Anomalies in Air Temperature 2018. https://www.dwd.de/EN/climate_environment/clima teatlas/climateatlas_node.html.

25. German Weather Service (DWD). German weather in summer 2018. https://www.dwd.de/DE/presse/pressemitteilungen/DE/2018/20180 830_deutschlandwetter_sommer_news.html. Accessed 20 Jan 2020.

26. Weiser C, Zeller V, Reinicke F, Wagner B, Majer S, Vetter A et al (2014) Integrated assessment of sustainable cereal straw potential and different straw-based energy applications in Germany. Appl Energy 114:1

27. Scarlat N, Fahl F, Lugato E, Monforti-Ferrario F, Dallemand JF (2019) Integrated and spatially explicit assessment of sustainable crop residues potential in Europe. Biomass Bioenergy 122:257-269

28. Lindner M, Dees MG, Anttila P, Verkerk PJ, Fitzgerald J, Datta P et al. Assessing Lignocellulosic Biomass Potentials From Forests and Industry. In: Modeling and Optimization of Biomass Supply Chains: Elsevier; 2017, p. 127-167.

29. Knebl L, Blumenstein B, Möller D, Wufka A, Brock C, Gattinger A. Soil turnover of cereal straw and fermentation residues of varying quality from straw fermentation: 15. Science Conference Ecologic Farming, Innovative thinking for a sustainable agriculture and food industry, Contributions to the 15th Scientific Conference on Organic Farming. https://orgprints.org/ 36243/. Accessed 05 Feb 2020

30. Blumenstein B, Knebl L, Gattinger A, Brock, Christopher, Wufka, André, Möller D. "Straw makes distance": On the economic efficiency of the (over-)operational logistics of Corg: 15. Science Conference Ecologic Farming 05.-08.03.2019, Innovative thinking for a sustainable agriculture and food industry, Contributions to the 15th Scientific Conference on Organic Farming. https://orgprints.org/36218/. Accessed 05 Feb 2020

31. Reinhold G. Points of view - Straw fermentation in agricultural biogas plants. http://www.tll.de/www/daten/publikationen/standpunkte/st_ bstroh.pdf. Accessed 05 Feb 2020

32. European Commission. Second NER 300 low-carbon project kicks off. https://ec.europa.eu/clima/news/articles/news_2015041501_en. Accessed 28 Jan 2020

33. Bill R (2016) Grundlagen der Geo-Informationssysteme: 6. Wichmann, Auflage. Berlin

34. European Parliament, Council of the European Union. Regulation (EC) No 1059/2003 of the European Parliament and of the Council of 26 May 2003 on the establishment of a common classification of territorial units for statistics (NUTS). https://eur-lex.europa.eu/legal-content/EN/TXT/PDF/? uri=CELEX:02003R1059-20180118\&from=EN. Accessed 01 Feb 2020

35. Federal Agency for Cartography and Geodesy (BKG). Administrative areas 1:250 000 (levels), as of 01.01. (VG250 01.01.). https://gdz.bkg.bund.de/ index.php/default/digitale-geodaten/verwaltungsgebiete/verwaltung sgebiete-1-250-000-ebenen-stand-01-01-vg250-ebenen-01-01.html. Accessed 05 Feb 2020

36. Statistical Offices of the Federal Government and the Federal States. Yields of selected agricultural crops - 2009-2018 - regional depth: districts and cities: Harvest statistics, yields per hectare, Code table 4124101-03-4. http://www.regionalstatistik.de. Accesses 29 Jan 2020

37. Statistical Offices of the Federal Government and the Federal States. Cultivation on arable land in agricultural farms by type of crop - 2010, 2016 - regional depth: districts and cities: Agricultural structure survey, Agricultural census, Code table 41141-02-02-4. http://www.regionalst atistik.de. Accessed 29 Jan 2020

38. Federal Ministry of Justice and Consumer Protection (BMJV). Ordinance on the use of fertilisers, soil additives, growing media and plant additives in accordance with the principles of good fertilisation practice: DüV, 26. Mai 2017 (BGBI. I S. 1305). https://www.gesetze-im-internet.de/d_v 2017/index.htm|\#BJNR130510017BJNE002500000. Accessed 29 Jan 2020

39. Statistical Offices of the Federal Government and the Federal States. Cattle population 2009-2018, regional depth: districts and cities: Cattle population survey, Code table 41312-01-01-4. http://www.regionalst atistik.de. Accessed 29 Jan 2020

40. Statistical Offices of the Federal Government and the Federal States. Agricultural farms with livestock farming and number of animals - 2010, 2016 - regional depth: districts and cities: Agricultural structure survey, Agricultural census, Code table 41141-03-01-4. http://www.regionalst atistik.de. Accessed 29 Jan 2020

41. Statistical Office of the Federal Government (DESTATIS). Animals housed: federal states, 1950-2018, animal types: General representative livestock survey, Code table 41311-0002. http://www.destatis.de. Accessed 29 Jan 2020

42. Uhl C. Investigations into the suitability of horse manure as Biofuel: Doctoral thesis. https://mediatum.ub.tum.de/doc/1444447/1444447.pdf. Accessed 29 Jan 2020

43. Statistical Office of the Federal Government (DESTATIS). Agriculture, forestry and fisheries: Animal manure, stable farming, grazing, agricultural census/agricultural structure survey 2010. https://www.destatis.de/DE/ Themen/Branchen-Unternehmen/Landwirtschaft-Forstwirtschaft-Fisch erei/Produktionsmethoden/Publikationen/Downloads-Produktionsmeth oden/stallhaltung-weidehaltung-2032806109004.pdf?_blob=publicatio nFile. Accessed 29 Jan 2020

44. Fuchs C, Schuldt A, Kasten J (eds) (2012) Horse farming: Planning and calculation. Darmstadt, KTBL

45. Statistical Office of the Federal Government (DESTATIS). Area under cultivation (vegetables and strawberries): federal states, 1950-2018, vegetables in the open field: Vegetable harvest, area under cultivation, Code table 41215-0008. http://www.destatis.de. Accessed 29 Jan 2020

46. Statistical Office of the Federal Government (DESTATIS). Area under cultivation (vegetables and strawberries): federal states, 1950-2018, vegetables under foil: Vegetable harvest, area under cultivation, Code table 41215-0006. http://www.destatis.de. Accessed 29 Jan 2020

47. Balmer M (2010) Orchards: Business management and technical production calculations, 4th edn. Kuratorium für Technik und Bauwesen in der Landwirtschaft, Darmstadt

48. Statistical Office of the Federal Government (DESTATIS). Farms, harvest area, harvest quantity (edible mushrooms): Germany, 2012-2018, edible mushroom species: Mushroom harvest, Code table 41214-0001. http:// www.destatis.de. Accessed 29 Jan 2020

49. Horticulture: Outdoor and Greenhouse. Darmstadt: KTBL; 2017.

50. Landpack GmbH. Straw based packaging. https://landpack.de/en. Accessed 05 Feb 2020

51. Knüppel E, Gurgel A, Hansen H. Straw heating system Gülzow: Demonstration of a straw heating system with local heating network. https:// mediathek.fnr.de/media/downloadable/files/samples/b/r/brosch_re_ strohheizanlage_web.pdf. Accessed 05 Feb 2020

52. Sauter $C$, Lüdtke $O$, Niesmann T, Sauter B. Biomethane from straw: EU Funded Project "DE BIOH Verbiostraw" Production of biomethane from 100\% straw. https://www.verbio.de/en/products/verbiogas/biomethanefrom-straw/. Accessed 25 Feb 2020

53. Clariant $\mathrm{GmbH}$. Cellulosic Ethanol from Agricultural Residues: Think Sunliquid (R). https://www.clariant.com/de/Business-Units/New-Businesses/ Biotech-and-Biobased-Chemicals/Sunliquid. Accessed 05 Feb 2020

54. Klüßendorf-Feiffer A. Thrust suitability as a central control variable in harvest management: Using the example of four process engineering approaches. PhD Thesis. http://d-nb.info/996979158. Accessed 05 Feb 2020

55. Minol K. Plants in focus: Pinboard - all research relevant plants at a glance. https://www.pflanzenforschung.de/de/themen/pflanzen-im-fokus/. Accessed 05 Feb 2020

56. Forstreuter T. Types of Cereals. https://www.bauernhof.net/die-getreidear ten/. Accessed 05 Feb 2020

57. Statistical Office of the Federal Government (DESTATIS). Agricultural farms with livestock: Livestock: federal states, reference date, animal species, Code table 41141-0019 (Tier-5). http://www.destatis.de. Accessed 04 Feb 2020

58. Döhler H (ed) (2013) Key-figures biogas, 3rd edn. Darmstadt, KTBL

59. Lüdtke, Oliver (COO Verbio AG). Plant specific base data. Email. Leipzig; 2020

60. Bavarian State Institute for Agriculture (LfL). Biogas yields of 350 substrates. https://www.lfl.bayern.de/iba/energie/049711/. Accessed 10 Dec 2020

61. Kaltschmitt M, Hartmann H, Hofbauer H (eds) (2009) Energie aus Biomasse: Grundlagen, Techniken und Verfahren, 2nd edn. Springer, Berlin

62. Majer S, Oehmichen K, Kirchmeyr F, Scheidl S. Calculation of GHG emission caused by biomethane: Biosurf - Fueling Biomethane, D5.3. http:// www.biosurf.eu/wordpress/wp-content/uploads/2015/07/BIOSURF-D5.3. pdf. Accessed 28 Jan 2020

63. Federal Ministry of Transport and Digital Infrastructure (BMVI). Transport Sector in Figures 2019/2020: Volume 48. https://www.bmvi.de/Share 
dDocs/DE/Publikationen/G/verkehr-in-zahlen-2019-pdf.pdf?_blob= publicationFile. Accessed 31 Jan 2020

64. Working Group of the Cadastral Surveying Authorities of the States of the Federal Republic of Germany (AdV). Documentation to Modelling of the geoinformation of cadastral surveying (GeolnfoDok): Main Document Version 6.0. http://www.adv-online.de/GeolnfoDok/binarywriterservlet? imgUid=42b23fd2-1153-911a-3b21-718a438ad1b2\&uBasVariant=11111 111-1111-1111-1111-111111111111. Accessed 31 Jan 2020

65. Federal Agency for Cartography and Geodesy (BKG). Digital Basic Landscape Model (levels) (Basis-DLM). https://gdz.bkg.bund.de/index.php/ default/digitale-geodaten/digitale-landschaftsmodelle/digitales-basislandschaftsmodell-ebenen-basis-dlm-ebenen.html. Accessed 05 Feb 2020

66. Federal Agency for Cartography and Geodesy (BKG). Digital Landscape Model 1:250 000 (levels) (DLM250): Open Data. https://gdz.bkg.bund.de/ index.php/default/open-data/digitales-landschaftsmodell-1-250-000ebenen-dlm250-ebenen.html. Accessed 05 Feb 2020

67. Federal Agency for Cartography and Geodesy (BKG). Digital Landscape Model 1:1 000000 (levels) (DLM1000): Open Data. https://gdz.bkg.bund. de/index.php/default/open-data/digitales-landschaftsmodell-1-1-000000-ebenen-dlm1000-ebenen.html. Accessed 05 Feb 2020

68. Working Group of the Cadastral Surveying Authorities of the States of the Federal Republic of Germany (AdV). Official Real Estate Cadastre Information System (ALKIS). http://www.adv-online.de/AdV-Produkte/Liegenscha ftskataster/ALKIS/. Accessed 05 Feb 2020

69. European Environment Agency (EEA). CORINE Land Cover 1990, 2000, 2006, 2012, 2018. https://land.copernicus.eu/pan-european/corine-landcover. Accessed 05 Feb 2020

70. Federal Agency for Cartography and Geodesy (BKG). Corine Land Cover 10 ha (CLC10): Open Data. https://gdz.bkg.bund.de/index.php/default/ open-data/corine-land-cover-10-ha-clc10.html. Accessed 05 Feb 2020
71. Federal Ministry of Justice and Consumer Protection (BMJV). Regulation on the implementation of support schemes and the Integrated Administration and Control System (InVeKoSV). https://www.gesetze-im-internet. de/invekosv_2015/BJNR016610015.html. Accessed 05 Feb 2020

72. Pfeiffer A, Mertens, Anja, Brosowski, André, Thrän D. Marktschreier 4.0 The straw market in Germany. https://www.dbfz.de/fileadmin//user_ upload/Referenzen/Broschueren/DBFZ_Strohmarkt_in_Deutschland.pdf. Accessed 28 Jan 2020

73. Statistical Office of the Federal Government (DESTATIS). Agricultural census 2020. https://www.destatis.de/DE/Themen/Branchen-Unternehmen/ Landwirtschaft-Forstwirtschaft-Fischerei/Landwirtschaftszaehlung2020/_ inhalt.html

74. Schumacher B. Investigations into processing and conversion of energy crops into biogas and bioethanol. Zugl.: Hohenheim, Univ., Diss, 2008. Berlin: mbv; 2008

75. Pohl M, Mumme J, Heeg K, Nettmann E (2012) Thermo- and mesophilic anaerobic digestion of wheat straw by the upflow anaerobic solid-state (UASS) process. Biores Technol 124:321-327

76. Bill R, Lorenzen-Zabel A, Hinz M, Kalcher J, Pfeiffer A, Brosowski A et al (2020) OpenGeoEdu - A Massive Open Online Course on Using Open Geodata. ISPRS Ann. Photogramm. Remote Sens. Spatial Inf. Sci.V-5-2020:31-8

\section{Publisher's Note}

Springer Nature remains neutral with regard to jurisdictional claims in published maps and institutional affiliations.
Ready to submit your research? Choose BMC and benefit from:

- fast, convenient online submission

- thorough peer review by experienced researchers in your field

- rapid publication on acceptance

- support for research data, including large and complex data types

- gold Open Access which fosters wider collaboration and increased citations

- maximum visibility for your research: over 100M website views per year

At BMC, research is always in progress.

Learn more biomedcentral.com/submissions 